\title{
HOUSEHOLD PORTFOLIO ALLOCATION OVER THE LIFE CYCLE
}

James M. Poterba Andrew A. Samwick

Working Paper 6185 


\title{
HOUSEHOLD PORTFOLIO ALLOCATION OVER THE LIFE CYCLE
}

\author{
James M. Poterba \\ Andrew A. Samwick \\ Working Paper 6185 \\ http://www.nber.org/papers/w6185 \\ NATIONAL BUREAU OF ECONOMIC RESEARCH \\ 1050 Massachusetts Avenue \\ Cambridge, MA 02138 \\ September 1997
}

This paper was presented at the JCER-NBER conference on "The Economics of Aging" on May 8-9, 1997. We thank Makoto Saito, Steve Venti, and conference participants for helpful comments and Arthur Kennickell for assistance with the Surveys of Consumer Finances. Financial support from the National Institute on Aging and the National Science Foundation through grants to the National Bureau of Economic Research is gratefully acknowledged. This paper is part of NBER's research program in Aging. Any opinions expressed are those of the authors and not those of the National Bureau of Economic Research.

(C) 1997 by James M. Poterba and Andrew A. Samwick. All rights reserved. Short sections of text, not to exceed two paragraphs, may be quoted without explicit permission provided that full credit, including $(\mathbb{C}$ notice, is given to the source. 
Household Portfolio Allocation Over

the Life Cycle

James M. Poterba and Andrew A. Samwick

NBER Working Paper No. 6185

September 1997

JEL Nos. E21, G11

Aging

\section{ABSTRACT}

In this paper, we analyze the relationship between age and portfolio structure for households in the United States. We focus on both the probability that households of different ages own particular portfolio assets and the fraction of their net worth allocated to each asset category. We distinguish between age and cohort effects using data from the repeated cross-sections of the Federal Reserve Board's Surveys of Consumer Finances. We present two broad conclusions. First, there are important differences across asset classes in both the age-specific probabilities of asset ownership and in the portfolio shares of different assets at different ages. The notion that all assets can be treated as identical from the standpoint of analyzing household wealth accumulation is not supported by the data. Institutional factors, asset liquidity, and evolving investor tastes must be recognized in modeling asset demand. These factors could affect analyses of overall household saving as well as the composition of this saving. Second, there are evident differences in the asset ownership probabilities of different birth cohorts. Currently, older households were more likely to hold corporate stock, and less likely to hold tax-exempt bonds, than younger households at any given_age. These differences across cohorts are important to recognize when analyzing asset accumulation profiles.

James M. Poterba

Department of Economics

Massachusetts Institute of Technology

E52-350

Cambridge, MA 02139-4307

and NBER

poterba@mit.edu
Andrew A. Samwick

Department of Economics

Dartmouth College

6106 Rockefeller Hall

Hanover, NH 03755-3574

and NBER

samwick@dartmouth.edu 
The recent and prospective aging of the populations in developed countries has attracted attention in many nations, as the recent discussion in a World Bank (1994) report attests. The potential effects of population aging on social security systems and the level of private and national saving have drawn the most interest from both academics and policy analysts. In the United States, particular attention has focused on the adequacy of the Baby Boom generation's level of retirement saving; for conflicting reports on this question, see the Congressional Budget Office (1993) and Bernheim (1994). The way households allocate their accumulated saving across different assets, such as stocks, bonds, and real estate, has attracted less discussion, even though future economic security can depend as much on the way assets are invested as on the level of those assets. Asset allocation is also essential for understanding the behavior of individuals in the increasingly popular defined contribution pension plans that allow participants some discretion in their investment choices and for analyzing recent proposals for Social Security reform that call for mandatory saving accounts, with investment responsibility delegated to individuals. ${ }^{1}$

Although there is little empirical work on asset allocation, there is a theoretical literature on the optimal portfolio behavior of individuals at different ages. This work is characterized by some controversy, in part between academics and practical financial advisers. In the standard portfolio choice paradigm that underlies most of financial economics, the only factor that should explain age-related differences in portfolio structure is differential risk aversion. In this setting, if a household is endowed with a time-invariant risk tolerance, then

\footnotetext{
'Samwick and Skinner (1995) examine the adequacy of defined contribution plans relative to the defined benefit plans that were popular before the transition began. Advisory Council on Social Security (1996) reports on various reform proposals for the United States system.
} 
there should be no age-related patterns of portfolio allocation. Conditional on a household's risk aversion, there are strong predictions regarding the mix of risky and riskless assets that a household should hold. Moreover, regardless of their risk aversion, all households should hold risky assets in the same proportions within their risky asset portfolios.

A number of studies have tried to relate this theoretical result to the common practical recommendation, documented by Canner, Mankiw, and Weil (1997), that households should change the relative proportions of risky assets in their portfolios as they age. Samuelson $(1989,1990)$ has considered the conditions on utility functions and asset returns that will lead to age-related differences in risky asset holdings; in essence, his analysis allows for timevarying risk tolerance. Other studies expand the traditional model of portfolio choice to study related aspects of life cycle asset allocation. For example, if individuals can vary their labor supply to offset fluctuations in asset returns, as in Bodie, Merton, and Samuelson (1992), or if they accumulate assets in part for precautionary reasons, as in Kimball (1993), and nonfinancial risks increase with age, then rational behavior may lead to a reduction in risky asset exposure as households age.

This paper complements the substantial theoretical discussion of age-related patterns in asset allocation. It presents systematic empirical evidence on the basic patterns of household asset allocation over the life cycle. This information can help to evaluate competing models of household portfolio behavior, and more generally to assess proposals for greater reliance on household choices in retirement preparation. Using multiple waves of the Surveys of Consumer Finances, we are able to control for systematic differences across birth cohorts in the age-specific pattern of asset ownership. We find that it is not possible to 
aggregate households born at different ages for the purpose of portfolio modelling: there are statistically and economically significant "cohort effects" for most types of financial and nonfinancial assets.

The paper is organized as follows. The first section describes the Surveys of Consumer Finances and presents summary statistics for each wave of data. Section two presents our econometric methodology for distinguishing age and cohort effects and analyzes the patterns of ownership and allocation of financial assets. The third section places the analysis of financial assets within the context of households' comprehensive balance sheets. The final section discusses several implications of our results, as well as directions for further research.

\section{Data Description}

The Surveys of Consumer Finances (SCFs) conducted by the Federal Reserve Board are designed to be the most comprehensive sources of wealth data in the United States. They are collected every three years, with the first one done in 1983 and the latest one (for which a final public release is available) in 1992. Although there are limited panel dimensions between the 1983 and 1986 and 1989 surveys, our analysis uses the SCFs from 1983, 1989, and 1992 as repeated cross-sections. We omit the 1986 survey because it was a limited reinterview survey of the households from the 1983 survey that does not permit us to distinguish between all of the asset and debt categories that are found in the other surveys. Avery and Elliehausen (1988), Avery and Kennickell (1988), Kennickell (1992), and Kennickell (1995) provide documentation of the SCFs from 1983, 1986, 1989, and 1992, 
respectively.

An important feature of the SCFs is that they combine an area probability sample of U.S. households with a sample of high income households drawn from tax records. The oversampling of high income households allows the SCFs to provide an accurate assessment of the upper tail of the distribution of wealth in the United States. ${ }^{2}$ In total, there are 4103, 3143, and 3906 observations in the three SCFs. In this section, we present summary statistics on financial and total assets.

Table 1 provides descriptive statistics for holdings of financial assets in each of the survey years; we consider the allocation of net worth in a later table. The six main categories of financial assets are taxable equity; tax-exempt bonds; taxable bonds; tax-deferred accounts such as Individual Retirement Accounts (IRAs), Keoghs, and defined contribution pension plans (including 401(k) plans); bank accounts (including certificates of deposit and money market accounts); and other financial assets such as whole life insurance and trusts. In each case, we assign mutual fund assets to the asset category corresponding to the assets held by the mutual fund. In addition, we distinguish between taxable equity held directly in brokerage accounts and that held indirectly through mutual funds.

Table 1 is divided into three parts. The three panels show the probability that a household owns a given asset, the average share of the household's portfolio in a given asset, and the share of total financial assets accounted for by each asset. More formally, for each

${ }^{2}$ Curtin, Juster, and Morgan (1989) compare the SCF 1983 to the wealth information in the 1984 Panel Study of Income Dynamics and the 1984 Survey of Income and Program Participation. 
financial asset $j$ in each survey year, we define $y_{i j}$ as household $i$ 's holdings of asset $j$; $Y_{j}$ is household i's total financial assets; $w_{i}$ is the sample weight of household $\mathrm{i}$; and $\mathrm{N}$ is the number of households in the given year's sample. ${ }^{3}$ We then tabulate:

$$
\begin{aligned}
& \text { Probability of O wnership }=\frac{\sum_{i=1}^{N} w_{i}\left(y_{i j}>0\right)}{\sum_{i=1}^{N} w_{i}} \\
& \text { A verage Portfolio Share }=\frac{\sum_{i=1}^{N} w_{i} \frac{y_{i j}}{Y_{i}}}{\sum_{i=1}^{N} w_{i}} \\
& \text { Aggregate Portfolio Share }=\frac{\sum_{i=1}^{N} w_{i} y_{i j}}{\sum_{i=1}^{N} w_{i} Y_{i}}
\end{aligned}
$$

The average portfolio share measures the allocation of the typical household, while the aggregate portfolio share measures the allocation of all households taken together. These portfolio shares will diverge to the extent that households with higher wealth levels have different allocations of financial assets than those with lower wealth.

The results on ownership probabilities in the upper panel of Table 1 suggest several broad patterns. First, the probability of owning taxable equity, excluding ownership through retirement accounts, was relatively constant over the 1983-1992 period. This constancy occurs even though the probability of direct equity ownership declined over this time period.

\footnotetext{
${ }^{3}$ Wolff $(1987,1994,1997)$ has argued that the SCFs need to be reweighted in order to match the aggregate totals in the Flow of Funds accounts of household net worth. Because it is not clear that the Flow of Funds are a more appropriate benchmark, we use the recommended weights provided with the SCFs without any adjustment.
} 
A rising probability of equity ownership through mutual funds accounts for the difference. The rising ownership of tax-deferred accounts during this period, however, and the attendant equity ownership through these accounts, results in a substantial increase in the total number of households who own corporate stock.

Second, the fraction of households owning tax-exempt bonds increased by about three percentage points between 1983 and 1992. This reflects the declining ownership of taxexempt securities by commercial banks and insurance companies over this period. There is also a roughly-equal increase in the probability of owning taxable bonds.

Third, there is a sharp increase in tax-deferred asset ownership: the probability of ownership rises by roughly 5.5 percentage points between 1983 and 1992 . This reflects the expansion of Individual Retirement Accounts in the early 1980s and the rapid growth of 401(k) plans and related retirement saving plans in the late 1980s and early 1990s. Poterba, Venti, and Wise (1996) summarize these developments.

Fourth, the probabilities of owning bank accounts and other financial assets were roughly unchanged over the period. This reflects in part the high initial market penetration for these accounts and the continued household reliance on these accounts for a variety of financial functions.

The two lower panels of Table 1 underscore the important difference between the average portfolio and the aggregate portfolio. For example, while assets in bank accounts represented 52.2 percent of the total financial assets in the average portfolio, they accounted for only 25.4 percent of total financial assets in household portfolios. The portfolios of higher net worth households are therefore less heavily invested in bank accounts and similar 
assets than are those of lower net worth households. There are corresponding differentials between the average portfolio and aggregate portfolio share in taxable equity, 6.15 percent versus 19.8 percent, and in tax-exempt bonds, 2.0 versus 9.4 percent.

The data on aggregate portfolio shares shown in the last panel of Table 1 track the substantial growth of assets held in tax-deferred accounts between 1983 and 1992. Assets in these accounts represented 14.7 percent of total financial assets in 1983, compared with 26.7 percent in 1992. The importance of these assets in the average portfolio also rose sharply during this period.

Table 1 presents summary information on portfolio allocation for all households, pooling those of different age categories. One group of households that attracts particular attention in studies of saving behavior and portfolio choice is the elderly. Because wealth accumulation typically takes place over a household's entire working life, elderly households have higher assets, on average, than younger households. Their behavior is therefore weighted more than the behavior of younger households in determining the composition of the aggregate household portfolio. In addition, for the elderly who have accumulated limited assets, the portfolio choices made early in retirement can determine the resources available for the later years of retirement.

Because the elderly are of special interest, Table 2 presents information analogous to that in Table 1, but only for those households headed by someone over the age of 65 . Many of the broad patterns resemble those in the earlier table. The bank account share of the average household's portfolio, 65.5 percent in 1992, is almost twice the share in the aggregate portfolio for elderly households (36.9 percent). Tax deferred assets grew less quickly 
between 1983 and 1992 for elderly households than for the entire population, reflecting the link between employment and access to these accounts. The aggregate portfolio held by elderly households differs from that for all households in that it includes more equity ( 23 percent versus 20 percent of total financial assets), more assets in bank accounts ( 37 percent versus 25 percent), and more holdings of taxable and tax exempt bonds ( 20 percent versus 16 percent). The greater portfolio shares in each of these categories are counterbalanced by significantly lower holdings in tax-deferred accounts, 11 percent versus 27 percent, for elderly as opposed to all households.

Table 3 presents more detailed information on the total holdings of financial assets by households of different ages in each of our sample years. The table is designed to highlight cohort-related differences in both the level of financial assets and the accumulation of financial assets over the nine years spanned by the data. The two panels of Table 3 present the mean and median financial asset holdings in each survey year by various birth cohorts, which we define as including households headed by individuals who were born within three years of each other. We identify each cohort by the age that the households born in its middle year had attained in 1983. The "age 28 cohort," for example, includes all households in which the head of household was born in 1954,1955 , or $1956 .{ }^{4}$ This cohort was between 27 and 29 years old in 1983, between 33 and 35 in 1989, and between 36 and 38 in 1992. All of the entries in Table 3 are reported in constant 1992 dollars, and standard errors are reported in parentheses below the means or medians.

\footnotetext{
${ }^{4}$ We define the head of household for a married couple to be the spouse that earned more labor income or, if neither worked, the older spouse. It is therefore possible that a given household would be part of different cohorts in different years if the head of the household stops being the primary earner or leaves the household. This may account for some of the anomalies in the tabulations of assets at older ages.
} 
Table 3 shows a number of interesting patterns in asset accumulation. For example, the information in the table can be used to compare asset accumulation across households in different cohorts. To illustrate these comparisons, consider the cohort that was 28 in 1983. The mean financial assets for this cohort, $\$ 30,583$ in 1989 and $\$ 27,315$ in 1992, were somewhat lower than those of the cohorts that were $34(\$ 33,182)$ and $37(\$ 31,195)$ in 1983 , respectively. This could lead to a conclusion that households in the younger cohort were saving less than those in older cohorts. Bernheim and Scholz (1995) focus on comparisons of this type in their recent study of retirement saving by the "Baby Boom" generation.

The data in Table 3 show that households enter a period of fairly rapid accumulation of financial assets when they are about 34 years old, and that their holdings of financial assets peak at about age 58. Movements in mean asset holdings are more pronounced than movements in the median, reflecting the well documented fact that many households don't ever accumulate particularly large stocks of financial wealth. ${ }^{5}$

The last three rows of Table 3 present summary information on total financial assets for three groups of households in each sample year: all households, all households with a head over the age of 62 , and all households with a head over the age of 65 . The comparisons of these groups illustrate the greater financial assets of the elderly than of households in general. In 1992, the average household headed by someone over the age of 65 held $\$ 102,917$ in financial assets, compared with $\$ 70,028$ for all households. Median financial assets for both the elderly $(\$ 14,550)$ and all households $(\$ 9,779)$ are much lower than mean

\footnotetext{
${ }^{5}$ Poterba,Venti, and Wise (1994) show that the wealth distribution for households at retirement age is highly skewed, and that many households reach retirement with virtually no resources other than the annuity value of Social Security and the equity in their home.
} 
assets, but they show the same pattern as the means.

Comparisons of mean and median financial assets for the elderly households in the three Surveys of Consumer Finance raise some questions. The mean financial assets of households over the age of 65 in 1989 was nearly twenty percent lower than the comparable mean assets for households over age 65 in 1983, and ten percent lower than the value for comparable households in 1992. Yet median assets were higher for the age $65+$ cohort in 1989 than in either 1983 or 1992 . The patterns of mean and median asset holdings for all households do not exhibit such reversals of trend; both mean and median financial assets for the whole population were higher in 1992 than in 1989, and higher in 1989 than in 1983.

Table 3 focuses on total financial assets, the sum of all of the asset categories we considered in Table 1. We also construct a measure of household net worth. One component of net worth is total assets, which includes total financial assets as well as holdings of owneroccupied real estate, other real estate assets, net equity in personally owned businesses, and miscellaneous assets. The other component is total debt, which equals the sum of financial debt, owner-occupied real estate debt, other real estate debt, and miscellaneous debt. We do not include the actuarial present value of Social Security benefits (net of taxes), or of benefits paid by defined benefit pension plans, in our measure of net worth.

Table 4 presents summary statistics on the ownership and allocation of the various components of net worth. The table is structured in the same way as Table 1, which described financial assets. Several findings on the ownership patterns for non-financial assets bear comment. Between 1983 and 1992, the probability of holding owner-occupied real estate assets stayed roughly constant, while the probability of owing debt on owner-occupied 
real estate increased. There were decreases in the probabilities of holding other real estate assets, business assets, and miscellaneous debt, and little change in the probabilities of owning financial assets, financial debt, and other real estate debt.

The second and third panels of Table 4 show an increase in the share of household debt between 1983 and 1992, and they suggest that this increase is particularly important for lower net worth households. ${ }^{6}$ The middle panel in Table 4 shows that for the average household, as a share of total assets, financial debt rose by 1.2 percentage points, owneroccupied real estate debt rose by 2.8 percentage points, and other debt rose by 3.6 percentage points. The aggregate household balance sheet shows an increase in owner-occupied real estate debt of 3.3 percentage points over the same period, but little increase in other debt components.

The two panels also show a shift in the composition of total assets away from personally owned businesses and toward miscellaneous assets, with little or no change in the proportion of financial and real estate assets. The bottom panel shows that total assets are on average comprised of 30 percent financial assets, 32 percent owner occupied real estate, 15 percent other real estate, 17 percent business net worth, and 6 percent miscellaneous assets.

Table 5 presents information similar to that in Table 4, but the sample is restricted to households with heads over the age of 65 in each year. There are some differences between the elderly and the population at large in the evolution of net worth. Owner-occupied housing, for example, became a more important component of net worth between 1983 and

\footnotetext{
${ }^{6}$ To scale the value of net worth components relative to the average and aggregate portfolio, we divide each component by total assets, rather than net worth, since approximately ten percent of the households report negative net worth in each year, and for these households, dividing by net worth would yield unreliable data values.
} 
1992 for elderly households, but not for households in general. The probability that an elderly household would own a home rose from 74.6 percent to 77.7 percent over this nine year period, and the aggregate share of owner-occupied housing as a fraction of total assets held by elderly households rose from 24.3 percent to 28.8 percent. This increase is not substantially offset by an expansion of mortgage debt. Over the 1983-1992 time period, financial assets became less important as a fraction of total assets for elderly households, with a decline from 41.6 percent to 38 percent. This occurred coincident with an increase in the importance of financial assets, relative to total assets, for the entire population.

Comparisons between the elderly population and the population in general also reveal differences in the composition of net worth. Owner-occupied real estate constitutes a smaller share of total assets, 28.8 percent, for the elderly than for households of all ages (33 percent). Financial assets are substantially more important for the elderly, and business net worth, an asset that is likely to be correlated with active participation in a business, is less important. Total debt, and especially owner-occupied debt, as a fraction of total assets are lower for the elderly than for the general population.

Table 6 shows the age-specific pattern of mean and median net worth for each of the sample years. Once again, households are categorized by the age of the household head in 1983; this is the same classification scheme used in Table 3 above. The data in this table provide the most direct evidence on the extent of household wealth accumulation at different ages. Several findings deserve commentary. First, net worth tends to peak when households are in their early sixties. Median net worth at this peak, in 1992 , was roughly $\$ 130,000$; mean net worth was roughly three times greater. Second, both mean and median net worth 
rose between 1983 and 1992 for households that were less than 52 years old in 1983, but beyond this age, net worth did not increase and in many cases declined. Finally, the large standard errors on the net worth entries make it difficult to draw strong conclusions at some ages. This is particularly important to remember when evaluating the findings for older households, where there is some evidence that net worth moves in one direction between 1983 and 1989, and then in another direction between 1989 and 1992.

Table 7 is similar to Table 6, except that it shows the age-specific pattern of total asset holdings rather than net worth. These summary statistics are of interest for two reasons. First, the provide important background for interpreting the graphs shown below on the share of total assets that are allocated to various asset categories at different ages. Second, they present some information on gross asset accumulation profiles. As an illustration of this use of the data, the results suggest that young households, those between the ages of roughly twenty and thirty-five, accumulated assets over the 1983-1992 period. For older households, the large standard errors on the cohort-specific asset values in each year make it more difficult to draw strong conclusions about the slope of the age-assets profile.

\section{Financial Asset Allocations}

The summary statistics presented in the last section provide important evidence on the nature of household portfolios in a cross-section of households, and on the evolution of household portfolios over time. In this section, we impose additional structure on the net worth and asset ownership data, and we decompose changes in financial asset allocation into 
age and cohort effects. Our methodology is based on a specification of the form:

$$
f\left(y_{i j}\right) \quad \alpha=+\sum_{n=2} \beta_{n} a g e_{i, n}+\sum_{m=2}^{21} \gamma_{m} \text { cohort }_{i, m}+\epsilon_{i, j}
$$

where $y_{i j}$ is the holdings of asset ' $j$ ' by household ' $i$,' age $e_{i, n}$ is a dummy variable for whether the current age of the household head is in the three-year interval centered on Age $=3^{*} n+$ 16 , and cohort $t_{i, m}$ is a dummy variable for whether age of the household head in 1983 fell in the three-year interval centered on Age $=3 * m+16$. Because of the oversampling of the high-income households in the Surveys of Consumer Finances, we estimate equation (2) using the year-specific sample weights, normalized so that the sum of the weights for the whole population in each year is the same.

We estimate equation (2) for each financial asset category with two forms of the dependent variable. The first is a probit for whether the household has positive amounts of the asset category $\left(y_{i j}>0\right.$ in equation (1)). The second is a Tobit for the share of the household's total financial assets that is held in each category $\left(\mathrm{y}_{\mathrm{ij}} / Y_{\mathrm{i}}\right.$ in equation (1)). These dependent variables correspond to summary information presented in the earlier tables.

For each specification, we focus on three issues in interpreting the results. The first is whether the cohort effects are significantly different from zero, or alternatively, whether there appear to be year-of-birth related differences in the asset allocation patterns of households. Consider the null hypothesis

$$
H_{0}: \gamma_{m}=0 \forall m
$$

Estimates of equation (2) with this constraint imposed are "no cohort effects" specifications; estimates without this constraint allow for cohort effects. We use a likelihood ratio test to 
determine whether the cohort effects are jointly significant. If they are, then different birth cohorts have significantly different probabilities of holding or portfolio shares of given financial assets. Finding that there are cohort effects in asset demands implies that data from different birth cohorts that comprise a single cross-section may be difficult to aggregate.

The second issue that we consider is whether there is the presence or absence of patterns in the estimated age coefficients, $\beta_{\mathrm{n}}$. These estimates reveal whether households follow the precepts of the simplest models of portfolio choice with time-invariant risk aversion, which imply that $\beta_{\mathrm{n}}=0$ for all $\mathrm{n}$, or the precepts of financial planners, who often suggest $\beta_{n+1}<\beta_{n}$ for risky assets. Much of the remainder of this section is devoted to describing the pattern of cohort effects for different asset categories.

Finally, we are interested in the methodological question of how the estimated age coefficients $\left(\beta_{n}\right)$ change when cohort effects are introduced into the specifications. Any changes will illustrate the importance of utilizing repeated cross-sections, as opposed to static cross-sections, to analyze portfolio allocations.

Figure 1 illustrates our graphical methodology for presenting the results of this estimation. The first graph displays two age-ownership profiles for equity held in taxable brokerage accounts. The profile depicted with triangles represents the predicted values from a regression of equation (2) without cohort effects. This profile is therefore the age-ownership profile that one would expect to find in any population cross-section. The profile is increasing with age until age 43 , when it peaks at around 22 percent of households owning corporate stock directly. The profile levels off after age 43 , with a slight decline at much older ages. 
The profile depicted with circles in Figure 1 represents the predicted values from equation (2) allowing for cohort effects. The predicted values at each age are based on the cohort effect for those households who were age 28 in 1983. This particular cohort is roughly the middle cohort in the United States' Baby Boom generation. The slope of the ageownership profile for this cohort is very close to the cross-sectional profile until roughly age 43, but, after that age, the cohort-specific profile is much lower. This difference implies that a given cohort of households can be expected to divest their direct equity holdings as they age faster than the cross-section evidence suggests (i.e., the cohort-specific probabilities of directly owning corporate stock have been declining over time).

The cohort effects are identified by the differences in the ownership probabilities of different cohorts at the same age, which naturally occurs in different years of the survey. The second graph, located in the lower left hand comer of Figure 1, shows the predicted probability that households born in each cohort will own taxable equity when they reach age 46. The use of age 46 is only a normalization; the shape of this curve would be the same for any age, since it depends only on the pattern of cohort effects. The vertical line in this figure indicates the cohort that was age 28 in 1983; this point corresponds to the same point on the first graph (line with circles).

Table 8 reports statistical tests for the importance of cohort effects for various asset categories. The entries in the first row are the p-values for the joint significance of the cohort effects in the two specifications we consider. The results show that there are statistically significant differences in ownership probabilities across different cohorts. Figure 1 helps the interpretation of this finding, since it shows that older cohorts were more likely to hold equity 
directly than were younger cohorts over this time period. ${ }^{7}$

The two graphs in the right panel of Figure 1 present the predicted values, by age and cohort, for estimates of equation (2) in which the dependent variable is the household's share of financial assets allocated to directly held stock. ${ }^{8}$ The divergence between the ageallocation profiles with and without cohort effects mirrors the divergence in the ageownership profiles. Average asset allocations to directly held equity peak at about five percent at age 43 and decline thereafter. Compared to the ownership profile, the allocation profile rises to this peak less rapidly and declines more rapidly.

Table 8 shows the p-value for the joint significance of the cohort effects. The null hypothesis of no cohort effects is rejected at standard significance levels. As in the estimates of ownership probabilities, the cohort effects are increasing with the household's age. This suggests that currently older cohorts of households tend to devote a higher fraction of their assets to directly-held stock.

We now employ the graphical analysis of Figure 1 for other asset categories. Figure 2 shows analogous graphs for all taxable equity, including brokerage accounts as well as equity mutual funds. These graphs demonstrate that the patterns in Figure 1 reflect changes in the institutional arrangements for holding the equity, rather than changes in age-specific patterns of equity ownership per se. The graphs in the upper panel of Figure 2 reveal virtually no

\footnotetext{
'It is not possible to simultaneously estimate age, cohort, and year effects without imposing functional form restrictions, such as a quadratic specification in age or a linear time trend. As a result, our identifying assumption may in fact be the result of secular trends toward lower directly held equity ownership.

${ }^{8}$ The estimates of equation (2) with asset shares as the dependent variable do not impose the adding up constraint on the asset shares for taxable equity, tax-exempt bonds, taxable bonds, tax-deferred accounts, bank accounts, and other financial assets, that they must sum to unity.
} 
differences in the age profiles of ownership and allocation when cohort effects are included in the model. The relatively flat age profiles suggest that households do not necessarily follow the popular financial advice to switch from stocks to bonds as they approach retirement. ${ }^{9}$ The cohort differences in ownership and allocation in the bottom graphs do not display a strong pattern with the household's age in 1983. Additionally, the p-values shown in Table 8 for the joint significance of the cohort effects show that the null hypothesis of no cohort effects is not rejected at standard significance levels.

Figure 3 shows the age profiles for tax-exempt bonds. Both direct and indirect holdings of tax exempt bonds (through mutual funds) are included in the statistics that underlie both of these figures. The age profiles for tax-exempt bonds are sharply increasing when cohort effects are included, in contrast to the flat profile found in the cross-section. The difference is primarily due to the statistically significant and downward sloping pattern of cohort effects shown in the bottom graphs. Although the current generation of older cohorts does not hold tax-exempts, the youngest generations do hold them, and this is reflected in the estimated cohort effects. These findings are consistent with the growing importance of municipal bonds as a retail financial asset, and with the greater experience with this asset on the part of younger households.

The age profiles for taxable bonds in Figure 4 resemble those for taxable equity, in that the profiles increase rapidly until about age 40 and remain steady thereafter. The profiles for taxable bonds that exclude cohort effects turn sharply lower after the peak, indicating that

\footnotetext{
${ }^{9}$ Since tax-deferred accounts may also be invested in equities, households could be reducing their overall equity positions if they were lowering the equity share of their tax-deferred accounts.
} 
a cross-sectional analysis would overstate the reduction in taxable bond holdings over the life cycle. The bottom graphs show a sharply declining pattern of cohort effects in both ownership and allocation.

Figure 5 presents the graphs for assets held in tax-deferred accounts, including Individual Retirement Accounts (IRAs), Keoghs, defined contribution (DC) pension plans, and other employer-sponsored retirement accounts such as $401(\mathrm{k})$ plans. ${ }^{10}$ In all cases, the investment earnings on these accounts are not taxed as they compound, and, in most cases, the initial contributions to the accounts are tax-deductible. Income tax is typically due only when the proceeds of the account are received as income in retirement. ${ }^{\text {"I }}$ As in the case of taxable bonds, the profiles with cohort effects do not slope downward later in life to the extent that the profiles without cohort effects do. The estimates predict that the cohort that was age 28 in 1983 will hold approximately one third of its financial assets in tax-deferred accounts when it reaches age 60 , and more generally, that younger cohorts will rely much more heavily on tax-deferred accounts than did earlier generations.

There is some decline with age in the reliance on traditional bank accounts, including certificates of deposit and money market accounts, and in the holdings of other financial

\footnotetext{
${ }^{10}$ The SCFs from 1989 and 1992 also report information on the assets that are actually owned in the taxdeferred accounts (e.g., stocks or bonds). Because the SCF from 1983 does not provide this information, we do not disaggregate this category further. Poterba, Venti, and Wise (1997) project the current rates of age-specific 401(k) contributions for individuals born in 1960 and 1970. They find that assuming that $401(\mathrm{k})$ assets are invested in bonds, the mean $401(\mathrm{k})$ assets at retirement will be $\$ 50,111$ (in constant 1992 dollars) for the 1960 cohort and $\$ 66,765$ for the 1970 cohort. If these assets are invested in the S\&P 500, however, and if the average return on stocks in coming decades is similar to that in the last seven decades, then the balances in $401(\mathrm{k}) \mathrm{s}$ will be $\$ 181,567$ and $\$ 256,056$ respectively. These asset balances would represent very large shares of household wealth at retirement, and could be compared with an actuarial value of Social Security wealth of $\$ 103,392$ on average.
}

${ }^{11}$ See Shoven and Wise (1996) for a careful analysis of the effective tax rates on tax-deferred accounts. 
assets, which are primarily the cash value of whole life insurance and trust accounts. Figure 6 presents the four graphs for bank accounts. ${ }^{12}$ The cohort effects in the portfolio share equation are statistically significant and increasing for older ages, suggesting that younger cohorts rely less on these fixed-income assets for holding wealth. Additionally, the ageownership profiles increase slowly with age while the age-allocation profiles decline over most of the life cycle. The cohort effects in the ownership specifications do not follow an obvious pattern over the life cycle, and in the case of Other Financial Assets, they are statistically indistinguishable from zero.

\section{Financial Assets in Total Net Worth}

This section extends our analysis of the asset ownership and allocation profiles to broader components of net worth. We consider aggregate financial assets, owner-occupied real estate, and holdings of business assets. The discussion and presentation parallels that for distinct classes of financial assets in the previous section.

Figure 7 graphs the ownership and allocation of financial assets as a share of total assets. The estimated age profiles for both ownership and allocation show an increase when households are young, followed by a decline until the household reaches age 40 . Thereafter, financial assets comprise a steadily increasing share of total assets. The cohort effects for ownership increase and then decrease over the life cycle. The cohort effects for the share of financial assets in total assets show a slightly increasing pattern with age in 1983.

Table 9 presents the results of tests for the joint significance of the cohort effects in

\footnotetext{
${ }^{12}$ The graphs for other financial assets are similar and therefore not presented.
} 
the ownership and asset allocation equations based on total assets. For the asset share equations for total financial assets, the null hypothesis of equal cohort effects is rejected at standard significance levels. The table also shows results for other asset categories, and with the exception of other real estate debt, finds statistically significant cohort effects for all asset categories.

Figure 8 presents the graphs showing ownership and share profiles for financial debt, which is the sum of outstanding balances on credit cards and lines of credit that are not directly secured by the value of real estate. The age-ownership profile shows increasing ownership with age at young ages, peaking at about 50 percent by age 43 and then falling steadily to below 20 percent at the oldest ages. Controlling for cohort effects leads to a somewhat sharper decline with age. Controlling for cohort effects has little effect on the age profile of financial debt as a share of total assets, which shows a similar pattern of a more rapid increase to a peak of about 7 percent at age 31 , declining to below 2 percent at the oldest ages. In both the ownership and allocation specifications, the cohort effects are statistically significant and the point estimates of these effects rise, slightly, between ages 30 and 60 (these ages correspond to the age of the household head in 1983).

Figures 9 and 10 show the graphs for owner occupied real estate assets and associated debt. Owner occupied real estate assets are simply the value of the household's primary residence. Owner occupied real estate debt includes the amounts remaining on mortgages and home equity loans on that property plus the outstanding balances on any lines of credit secured by the home. The age-ownership profile of owner occupied assets rises from about 10 percent for the youngest ages and then remains fairly steady above 70 percent for ages 
above 45 . More surprisingly, the fraction of total assets comprised by the value of owneroccupied assets remains steady at about 40 percent for all ages above the mid-30s. Though we reject the null hypothesis of no cohort effects in both cases, in neither case do cohort effects show a systematic pattern across different ages in 1983 or affect the shape of the age profiles.

The age-ownership profile of owner-occupied debt more closely resembles that of financial debt than of owner-occupied assets. It rises to a peak of about 60 percent at age 50 and then declines to about 10 percent at the oldest ages. As a percentage of total assets, the amount of owner-occupied debt peaks at about 25 percent between ages 43 - 52 and then declines to below 10 percent at the oldest ages. The cohort effects show a declining pattern with age in 1983, with the cohort aged 28 in 1983 predicted to have almost twice the share of debt in total assets when it reaches age 46 that the cohort aged 61 in 1983 had when it was 46. Younger generations clearly borrow against the value of their homes to a greater extent than did earlier generations. Controlling for cohort effects shifts the peak of the ageallocation profile by about 20 years, from 35 to $55^{13}$

Figure 11 plots the results for other real estate equity, which includes all real estate other than the primary residence, such as second homes properties held for investment purposes. We have combined both assets and debt into the same category in the graphs. The age profiles reach their peaks of 27 percent ownership and 7 percent allocation at about age 60 , and the inclusion of cohort effects tends to flatten out the profile. The cohort effects are

\footnotetext{
${ }^{13}$ Figure 11 is the most obvious example of a sharp increase in the age profile for one of the later age groups. Another example is Figure 9, which also pertains to a debt measure. Such upturns were present to a lesser extent in taxable equity and tax exempt bonds in the previous section. A reason why such irregularities are possible is that we have fewer observations at the higher ages than in the middle of the age distribution.
} 
statistically significant and show both an increasing pattern with age and substantial variation around this trend.

Figure 12 presents the results for net equity in personally owned businesses. These enterprises could be sole proprietorships, partnerships, or Subchapter S Corporations. In most instances, at least one member of the household actively manages the business. In other cases, the household holds a passive interest in the enterprise, such as a limited partnership. The age profile for ownership of net equity in a personally held business increases rapidly until about age 37 and then declines as the household ages. In the late thirties, about 15 percent of households own businesses and the average share of total assets comprised by business net worth is 5 percent. The declines are much more pronounced in the profile that includes cohort effects than in the profile that does not. The cohort effects are statistically significant and increasing with age in $1983^{14}$

The results presented in this section and the previous one suggest two broad conclusions. First, there are important differences across asset classes in the age-specific probability of asset ownership and in the fraction of household assets that are allocated to different assets at different ages. The notion that all assets can be treated as identical from the standpoint of analyzing household wealth accumulation is clearly not supported by the data. Households tend to accumulate liquid financial assets early in the life cycle, followed by accumulation of real estate and retirement saving assets. Second, there are evident differences in the asset ownership probabilities of different birth cohorts. Older households were more likely to hold corporate stock, and less likely to hold tax-exempt bonds, than

\footnotetext{
${ }^{14}$ In order to conserve space, the figures for miscellaneous assets and debts (consisting primarily of vehicles, collectibles, and other loans owed to or by the household) are omitted.
} 
younger households, at any given age. These differences across cohorts are important to recognize when analyzing asset accumulation profiles.

\section{Discussion and Conclusions}

The results presented in the previous two sections describe the evolution of household portfolios over the life cycle. Empirical evidence on the structure of household portfolios bears on a variety of questions in financial economics and public finance.

One question that our results address is the degree to which the standard life cycle framework of asset accumulation can be applied to different components of wealth. The life cycle model posits a "hump shaped" pattern of asset accumulation as households age: they accumulate assets during their working years and spend down those assets during their retirement years. Our results suggest that the hump-shaped pattern is not uniform across all assets. For example, as a percentage of total assets, financial assets show just the opposite pattern; they decline as households age, and then begin to increase at advanced ages. Investment real estate and equity in privately-held businesses do display a hump-shaped pattern, as in the life cycle model, but owner occupied housing does not, since there is no evident decline in its ownership at older ages. ${ }^{15}$

The standard life-cycle model does not distinguish between various types of assets. Yet when assets exhibit different degrees of liquidity, with for example financial assets more liquid than business net worth or other real estate assets, the age pattern of asset holdings may contain important clues for evaluating competing theories of saving behavior.

\footnotetext{
${ }^{15}$ Venti and Wise (1990) discuss the absence of substantial dissaving out of housing assets among the elderly.
} 
Precautionary saving models suggest that households should seek assets that can be liquidated in the event of a financial need. The different age profiles that we identify should therefore provide grist for future research on motives for saving.

A second issue that our findings address is the importance of cohort-specific factors, such as experience with historical returns on different assets, or exposure to financial advertisements, in shaping portfolio patterns. One result that our findings suggest is the important heterogeneity in the composition of portfolios across different cohorts. Our statistical tests show that cohort effects are significant for most components of financial assets and net worth. Among financial assets, the only category in which there was no trend in the cohort effects by age in 1983 was taxable equity. Baby Boomers show roughly the average propensity to hold taxable equity and the average portfolio share of taxable equity. Younger cohorts show greater investments in taxable bonds, tax-exempt bonds, and tax-deferred accounts than do older cohorts. They show lower investments in bank accounts and other financial assets. Compared to previous cohorts, the Baby Boom generation appears to be more willing to take advantage of the more sophisticated financial instruments that have become available over the past twenty years.

Younger cohorts have also leveraged their assets to a greater extent than older cohorts. The greater use of debt may also be the result of liberalization of financial markets over the last two decades. Nonetheless, the burden of servicing this debt will reduce the extent to which the Baby Boomers can use their assets to support consumption in retirement. Our results suggest that borrowing behavior should receive attention, along with asset accumulation, in studies of financial preparation for retirement. 
We explored some simple explanations for the estimated cohort effects by estimating asset holding and asset share specifications including other explanatory variables, such as the level of family income, the marginal tax rate on interest income, household size, and marital status, as well as the set of variables in equation (2). ${ }^{16}$ While these additional covariates generally improved the fit of the model, for most of the asset and debt categories we analyzed, the estimated age and cohort coefficients changed very little as a result of these specification changes.

Detailed analysis of particular asset categories may be needed to explain some of the cohort effects. For example, Samwick (1996) analyzes the market for tax-shelter investments in real estate, oil and gas, and other areas, before and after the Tax Reform Act of 1986 reduced the incentives for investing in tax shelters. Older cohorts may hold assets that were originally purchased as part of these tax shelter investments, while younger households may not hold these assets, because of the historical investment environment in which they made portfolio decisions. Further work modelling and explaining the nature of the cohort effects is clearly needed.

The important cohort patterns we identify suggest that it is essential to distinguish between the saving and asset accumulation of various cohorts as they approach retirement. The experience of one cohort as it approaches retirement may not translate to other, younger, cohorts. These results provide a warrant for the type of research now being undertaken, in many contexts, on the retirement planning and preparation of the Baby Boom cohort in the United States.

\footnotetext{
${ }^{16}$ Poterba and Samwick (1997) report more detailed results on some of these specifications, with a particular focus on how taxation affects asset demand.
} 
One significant issue that we have not addressed is the role of financial market frictions in explaining age-specific patterns of asset holding and portfolio structure. Downpayment requirements for purchasing owner-occupied homes are an example of such a friction. In most cases, households must accumulate a downpayment of between ten and twenty percent of house value before they can obtain a mortgage for the balance of their home. This could explain a pattern of financial asset accumulation for young households before they purchase a home, as well as the high level of real estate assets (and low level of financial assets) for households in the years immediately after home purchase.

Another example of institutional constraints that might affect accumulation profiles arises from tax-deferred retirement saving accounts. The rapid growth of these accounts has led to a substantial increase in the share of assets that many households hold through these accounts. Because these accounts make it easier for households to purchase some types of assets than others (traded equity or bonds are easy to hold in these accounts; net worth in private businesses would be much harder), the diffusion of these accounts may in part explain the shifting asset ownership patterns of different cohorts.

Further work is needed to explore the implications of life-cycle models with realistic financial market frictions, and alternative models of saving behavior based on precautionary or other factors, for the structure and development of household portfolios. The rich variation in portfolio structure provides a substantial body of information on motives for saving that has yet to be fully exploited. 


\section{References}

Advisory Council on Social Security (1996). Quadrennial Report. Washington: Social Security Administration.

Avery, Robert B. and Gregory E. Elliehausen (1988). 1983 Survey of Consumer Finances: Technical Manual and Codebook. Washington: Board of Governors of the Federal Reserve System.

Avery, Robert B. and Arthur B. Kennickell (1988). 1986 Survey of Consumer Finances: Technical Manual and Codebook. Washington: Board of Governors of the Federal Reserve System.

Bernheim, B. Douglas (1994). "Do Households Appreciate Their Financial Vulnerabilities? An Analysis of Actions, Perceptions, and Public Policy." Manuscript, Stanford University.

Bernheim, B. Douglas and J. Karl Scholz (1995). "Patterns of Saving by U.S. Households in the 1980s: Evidence from the Surveys of Consumer Finance." Manuscript, Stanford.

Bodie, Zvi, Robert C. Merton, and William F. Samuelson (1992). "Labor Supply Flexibility and Portfolio Choice in a Lifecycle Model." Journal of Economic Dynamics and Control 16 (July-Oct), 427-449.

Canner, Niko, N. Gregory Mankiw, and David N. Weil (1997). "An Asset Allocation Puzzle." American Economic Review 87 (March), 18 1-191.

Congressional Budget Office (1993). Baby Boomers in Retirement: An Early Perspective. Washington: U.S. Government Printing Office.

Curtin, Richard T., F. Thomas Juster and James N. Morgan (1989). "Survey Estimates of Wealth: An Assessment of Quality." in Lipsey and Tice (eds.) The Measurement of Saving, Investment, and Wealth. Chicago: University of Chicago Press, 473-552.

Kennickell, Arthur B. (1992). Description of the First Public Release of the Full 1989 SCF Cross-Section Dataset and 1989 Survey of Consumer Finances Codebook. Washington: Board of Governors of the Federal Reserve System.

Kennickell, Arthur B. (1995). 1992 Survey of Consumer Finances: Technical Manual and Codebook. Washington: Board of Governors of the Federal Reserve System.

Kimball, Miles S. (1993). "Standard Risk Aversion." Econometrica 61 (May), 589-611.

Poterba, James M. and Andrew A. Samwick (1997). "Taxation and Household Portfolio Composition: Evidence from Tax Reforms of the 1980s." Manuscript, Cambridge: 
Massachusetts Institute of Technology.

Poterba, James M., Steven F. Venti, and David A. Wise (1994). "Targeted Retirement Saving and the Net Worth of Elderly Americans." American Economic Review 84 (May), 180-185.

Poterba, James M., Steven F. Venti, and David A. Wise (1996). "How Retirement Saving Programs Increase Saving." Journal of Economic Perspectives 10, 91-112.

Poterba, James M., Steven F. Venti, and David A. Wise (1997). "Implications of Rising Personal Retirement Saving." Manuscript, National Bureau of Economic Research, April.

Samuelson, Paul A. (1989). "A Case At Last for Age-Phased Reduction in Equity."

Proceedings of the National Academy of Sciences 86 (November), 9048-9051.

Samuelson, Paul A. (1990). "Long Run Risk Tolerance When Equity Returns Are

Mean-Regressing: Pseudoparadoxes and Vindication of Businessman's Risk." in W. Brainard, W. Nordhaus, and H. Watts (eds.) Macroeconomics, Finance, and Economic Policy: Essays in Honor of James Tobin. Cambridge: MIT Press.

Samwick, Andrew A. (1996). "Tax Shelters and Passive Losses After the Tax Reform Act of 1986." in Martin S. Feldstein and James M. Poterba (eds.) Empirical Foundations of Household Taxation. Chicago: University of Chicago Press, 193-226.

Samwick, Andrew A. and Jonathan S. Skinner (1995). "How Will Defined Contribution Plans Affect Retirement Income?" Manuscript, Dartmouth College, June.

Shoven, John B. and David A. Wise (1996). "The Taxation of Pensions: A Shelter Can Become a Trap." National Bureau of Economic Research, Working Paper No. 5815.

Venti, Steven F. and David A. Wise (1990). "But They Don't Want To Reduce Housing Equity." in David A. Wise (ed.) Issues in the Economics of Aging. Chicago: University of Chicago Press.

Wolff, Edward N. (1987). "Estimates of Household Wealth Inequality in the United States, 1962-1983." Review of Income and Wealth 33 (September), 231-256.

Wolff, Edward N. (1994). "Trends in Household Wealth in the United States, 1962-1983 and 1983-1989." Review of Income and Wealth 40 (June), 143-174.

Wolff, Edward N. (1997). "Who Are the Rich? A Demographic Profile of High-Income and High-Wealth Americans." Manuscript, New York University, March.

World Bank (1994). Averting the Old Age Crisis: Policies to Protest the Old and Promote Growth. Policy Research Report Series. Oxford: Oxford University Press. 


\begin{tabular}{|c|c|c|c|}
\hline \multicolumn{4}{|c|}{$\begin{array}{c}\text { Table } \\
\text { Ownership and Allocation of Financial Assets for all Households, by Year }\end{array}$} \\
\hline Financial Asset & 1983 & 1989 & 1992 \\
\hline & \multicolumn{3}{|c|}{ Probability of Ownership } \\
\hline Taxable Equity & 20.15 & 19.04 & 20.98 \\
\hline Directly Held & 19.07 & 15.91 & 16.90 \\
\hline Tax-Exempt Bonds & 3.31 & 6.23 & 6.77 \\
\hline Taxable Bonds & 23.99 & 27.95 & 27.23 \\
\hline Tax-Deferred Accts & 32.86 & 37.85 & 39.33 \\
\hline Bank Accounts & 87.63 & 85.65 & 87.21 \\
\hline \multirow[t]{2}{*}{ Other Fin Assets } & 36.52 & 36.62 & 36.60 \\
\hline & \multicolumn{3}{|c|}{ Average Share of Household Portfolio } \\
\hline Taxable Equity & 5.78 & 5.53 & 6.15 \\
\hline Directly Held & 5.50 & 4.58 & 4.43 \\
\hline Tax-Exempt Bonds & 0.76 & 1.84 & 1.96 \\
\hline Taxable Bonds & 3.61 & 4.63 & 4.57 \\
\hline Tax-Deferred Accts & 15.14 & 19.59 & 21.67 \\
\hline Bank Accounts & 58.53 & 54.41 & 52.15 \\
\hline \multirow[t]{2}{*}{ Other Fin Assets } & 16.19 & 14.01 & 13.49 \\
\hline & \multicolumn{3}{|c|}{ Share of Aggregate Household Portfolio } \\
\hline Taxable Equity & 27.32 & 17.08 & 19.84 \\
\hline Directly Held & 26.43 & 14.82 & 16.18 \\
\hline Tax-Exempt Bonds & 7.15 & 9.69 & 9.37 \\
\hline Taxable Bonds & 6.26 & 7.68 & 6.42 \\
\hline Tax-Deferred Accts & 14.67 & 21.39 & 26.61 \\
\hline Bank Accounts & 27.73 & 30.61 & 25.44 \\
\hline Other Fin Assets & 16.87 & 13.54 & 12.32 \\
\hline
\end{tabular}


Table 2

Ownership and Allocation of Financial Assets for Households Over 65, by Year

\begin{tabular}{|c|c|c|c|c|}
\hline Financial Asset & & 1983 & 1989 & 1992 \\
\hline & & \multicolumn{3}{|c|}{ Probability of Ownership } \\
\hline Taxable Equity & & 22.77 & 20.63 & 21.73 \\
\hline Directly Held & & 21.41 & 18.04 & 17.44 \\
\hline Tax-Exempt Bonds & & 5.80 & 9.05 & 11.01 \\
\hline Taxable Bonds & & 20.44 & 23.49 & 23.84 \\
\hline Tax-Deferred Accts & & 7.92 & 17.78 & 20.74 \\
\hline Bank Accounts & & 86.75 & 91.11 & 90.37 \\
\hline \multirow[t]{2}{*}{ Other Fin Assets } & & 37.28 & 36.52 & 40.97 \\
\hline & & \multicolumn{3}{|c|}{ Average Share of Household Portfolio } \\
\hline Taxable Equity & & 7.89 & 6.53 & 6.76 \\
\hline Directly Held & & 7.45 & 5.55 & 4.74 \\
\hline Tax-Exempt Bonds & & 1.36 & 2.81 & 3.55 \\
\hline Taxable Bonds & & 4.35 & 5.71 & 4.84 \\
\hline Tax-Deferred Accts & & 2.50 & 6.56 & 7.63 \\
\hline Bank Accounts & & 72.37 & 68.60 & 65.50 \\
\hline \multirow[t]{2}{*}{ Other Fin Assets } & & 11.54 & 9.79 & 11.73 \\
\hline & & \multicolumn{3}{|c|}{ Share of Aggregate Household Portfolio } \\
\hline Taxable Equity & & 32.75 & 18.87 & 23.00 \\
\hline Directly Held & & 31.49 & 16.75 & 19.21 \\
\hline Tax-Exempt Bonds & & 10.56 & 13.28 & 11.84 \\
\hline Taxable Bonds & & 8.92 & 11.31 & 7.87 \\
\hline Tax-Deferred & Accts & 4.71 & 9.31 & 10.52 \\
\hline Bank Accounts & & 32.54 & 37.96 & 36.90 \\
\hline Other Fin Assets & & 10.53 & 9.27 & 9.88 \\
\hline
\end{tabular}




\begin{tabular}{|c|c|c|c|c|c|c|}
\hline \multicolumn{7}{|c|}{$\begin{array}{c}\text { Table } 3 \\
\text { Financial Asset Holdings by Cohort and Year }\end{array}$} \\
\hline \multirow{2}{*}{$\begin{array}{l}\text { Age } \\
\text { in } 1983\end{array}$} & \multicolumn{3}{|c|}{ Mean } & \multicolumn{3}{|c|}{ Median } \\
\hline & 1983 & 1989 & 1992 & 1983 & 1989 & 1992 \\
\hline 19 & $\begin{array}{c}3850 \\
(1641)\end{array}$ & $\begin{array}{c}6861 \\
(2297)\end{array}$ & $\begin{array}{l}14172 \\
(4026)\end{array}$ & $\begin{array}{c}419 \\
(285)\end{array}$ & $\begin{array}{l}1019 \\
(334)\end{array}$ & $\begin{array}{l}2769 \\
(766)\end{array}$ \\
\hline 22 & $\begin{array}{l}4362 \\
(930)\end{array}$ & $\begin{array}{l}21351 \\
(9763)\end{array}$ & $\begin{array}{l}20380 \\
(5632)\end{array}$ & $\begin{array}{l}1029 \\
(256)\end{array}$ & $\begin{array}{c}3450 \\
(1602)\end{array}$ & $\begin{array}{c}5050 \\
(1050)\end{array}$ \\
\hline 25 & $\begin{array}{l}7687 \\
(1014)\end{array}$ & $\begin{array}{l}20914 \\
(9579)\end{array}$ & $\begin{array}{l}25777 \\
(6989)\end{array}$ & $\begin{array}{l}1759 \\
(354)\end{array}$ & $\begin{array}{c}3730 \\
(1545)\end{array}$ & $\begin{array}{c}3579 \\
(1311)\end{array}$ \\
\hline 28 & $\begin{array}{c}9818 \\
(1235)\end{array}$ & $\begin{array}{c}30583 \\
(21500)\end{array}$ & $\begin{array}{l}27315 \\
(9668)\end{array}$ & $\begin{array}{l}1970 \\
(431)\end{array}$ & $\begin{array}{c}5329 \\
(1048)\end{array}$ & $\begin{array}{c}4500 \\
(1225)\end{array}$ \\
\hline 31 & $\begin{array}{l}13923 \\
(7872)\end{array}$ & $\begin{array}{c}43207 \\
(11043)\end{array}$ & $\begin{array}{c}40793 \\
(10198)\end{array}$ & $\begin{array}{l}2890 \\
(576)\end{array}$ & $\begin{array}{l}12899 \\
(3067)\end{array}$ & $\begin{array}{c}9100 \\
(1905)\end{array}$ \\
\hline 34 & $\begin{array}{l}33182 \\
(8545)\end{array}$ & $\begin{array}{c}36765 \\
(40992)\end{array}$ & $\begin{array}{c}54339 \\
(16492)\end{array}$ & $\begin{array}{l}10880 \\
(2064)\end{array}$ & $\begin{array}{l}11989 \\
(1840)\end{array}$ & $\begin{array}{l}12100 \\
(2848)\end{array}$ \\
\hline 37 & $\begin{array}{c}31195 \\
(44949)\end{array}$ & $\begin{array}{c}61509 \\
(31017)\end{array}$ & $\begin{array}{c}74160 \\
(20004)\end{array}$ & $\begin{array}{c}8750 \\
(1380)\end{array}$ & $\begin{array}{c}9649 \\
(2797)\end{array}$ & $\begin{array}{c}8779 \\
(2734)\end{array}$ \\
\hline 40 & $\begin{array}{l}35983 \\
(6603)\end{array}$ & $\begin{array}{c}63865 \\
(39118)\end{array}$ & $\begin{array}{c}78316 \\
(27374)\end{array}$ & $\begin{array}{c}8750 \\
(1793)\end{array}$ & $\begin{array}{c}8369 \\
(2948)\end{array}$ & $\begin{array}{l}16479 \\
(2613)\end{array}$ \\
\hline 43 & $\begin{array}{l}37911 \\
(9625)\end{array}$ & $\begin{array}{l}84058 \\
(28683)\end{array}$ & $\begin{array}{l}124963 \\
(31557)\end{array}$ & $\begin{array}{c}9170 \\
(2609)\end{array}$ & $\begin{array}{l}11390 \\
(3847)\end{array}$ & $\begin{array}{c}22200 \\
(10434)\end{array}$ \\
\hline 46 & $\begin{array}{c}81064 \\
(111616)\end{array}$ & $\begin{array}{c}81352 \\
(18713)\end{array}$ & $\begin{array}{l}104504 \\
(27794)\end{array}$ & $\begin{array}{l}11520 \\
(3534)\end{array}$ & $\begin{array}{l}20370 \\
(4751)\end{array}$ & $\begin{array}{l}19809 \\
(5911)\end{array}$ \\
\hline 49 & $\begin{array}{c}67821 \\
(33285)\end{array}$ & $\begin{array}{l}89496 \\
(39970)\end{array}$ & $\begin{array}{l}144769 \\
(56449)\end{array}$ & $\begin{array}{l}10170 \\
(2731)\end{array}$ & $\begin{array}{l}20479 \\
(8974)\end{array}$ & $\begin{array}{c}32279 \\
(16949)\end{array}$ \\
\hline 52 & $\begin{array}{c}49144 \\
(13479)\end{array}$ & $\begin{array}{c}96129 \\
(44938)\end{array}$ & $\begin{array}{l}124017 \\
(29567)\end{array}$ & $\begin{array}{l}12479 \\
(3678)\end{array}$ & $\begin{array}{r}10520 \\
(6884)\end{array}$ & $\begin{array}{l}30600 \\
(8643)\end{array}$ \\
\hline 55 & $\begin{array}{c}87258 \\
(38070)\end{array}$ & $\begin{array}{l}109603 \\
(28301)\end{array}$ & $\begin{array}{c}94693 \\
(50803)\end{array}$ & $\begin{array}{l}13409 \\
(2104)\end{array}$ & $\begin{array}{l}12449 \\
(4551)\end{array}$ & $\begin{array}{l}15260 \\
(4793)\end{array}$ \\
\hline 58 & $\begin{array}{c}94010 \\
(28594)\end{array}$ & $\begin{array}{l}102525 \\
(38764)\end{array}$ & $\begin{array}{c}80019 \\
(39221)\end{array}$ & $\begin{array}{l}21040 \\
(5096)\end{array}$ & $\begin{array}{l}20250 \\
(5687)\end{array}$ & $\begin{array}{l}10000 \\
(4452)\end{array}$ \\
\hline
\end{tabular}




\begin{tabular}{|c|c|c|c|c|c|c|}
\hline \multirow{2}{*}{$\begin{array}{l}\text { Age in } \\
1983\end{array}$} & \multicolumn{3}{|c|}{ Mean } & \multicolumn{3}{|c|}{ Median } \\
\hline & 1983 & 1989 & 1992 & 1983 & 1989 & 1992 \\
\hline 61 & $\begin{array}{c}91179 \\
(37106)\end{array}$ & $\begin{array}{l}107870 \\
(45402)\end{array}$ & $\begin{array}{c}112358 \\
(47727)\end{array}$ & $\begin{array}{r}19930 \\
(3738)\end{array}$ & $\begin{array}{r}11989 \\
(3756)\end{array}$ & $\begin{array}{l}23600 \\
(7759)\end{array}$ \\
\hline 64 & $\begin{array}{l}162507 \\
(68483)\end{array}$ & $\begin{array}{c}105022 \\
(30246)\end{array}$ & $\begin{array}{c}96608 \\
(45657)\end{array}$ & $\begin{array}{l}14140 \\
(4147)\end{array}$ & $\begin{array}{l}31450 \\
(9395)\end{array}$ & $\begin{array}{l}17899 \\
(7558)\end{array}$ \\
\hline 67 & $\begin{array}{l}126708 \\
(44063)\end{array}$ & $\begin{array}{c}91994 \\
(43808)\end{array}$ & $\begin{array}{c}96321 \\
(31806)\end{array}$ & $\begin{array}{r}14090 \\
(5613)\end{array}$ & $\begin{array}{c}21500 \\
(10848)\end{array}$ & $\begin{array}{c}28899 \\
(10550)\end{array}$ \\
\hline 70 & $\begin{array}{r}123968 \\
(36374)\end{array}$ & $\begin{array}{c}106879 \\
(37031)\end{array}$ & $\begin{array}{c}97555 \\
(58157)\end{array}$ & $\begin{array}{l}20559 \\
(5111)\end{array}$ & $\begin{array}{c}42259 \\
(13891)\end{array}$ & $\begin{array}{l}14550 \\
(7487)\end{array}$ \\
\hline 73 & $\begin{array}{c}117941 \\
(59195)\end{array}$ & $\begin{array}{c}74874 \\
(43876)\end{array}$ & $\begin{array}{c}94085 \\
(34098)\end{array}$ & $\begin{array}{r}15890 \\
(5392)\end{array}$ & $\begin{array}{c}5539 \\
(4806)\end{array}$ & $\begin{array}{c}6000 \\
(13079)\end{array}$ \\
\hline 76 & $\begin{array}{c}85727 \\
(74049)\end{array}$ & $\begin{array}{r}107124 \\
(98454)\end{array}$ & $\begin{array}{l}125394 \\
(98233)\end{array}$ & $\begin{array}{c}8430 \\
(3216)\end{array}$ & $\begin{array}{c}20819 \\
(10832)\end{array}$ & $\begin{array}{c}8000 \\
(6596)\end{array}$ \\
\hline 79 & $\begin{array}{c}75315 \\
(56431)\end{array}$ & $\begin{array}{c}52666 \\
(46839)\end{array}$ & $\begin{array}{c}134576 \\
(147614)\end{array}$ & $\begin{array}{r}12710 \\
(5887)\end{array}$ & $\begin{array}{l}11310 \\
(8539)\end{array}$ & $\begin{array}{c}48029 \\
(28254)\end{array}$ \\
\hline Over 62 & $\begin{array}{l}117782 \\
(23292)\end{array}$ & $\begin{array}{c}94749 \\
(18331)\end{array}$ & $\begin{array}{c}101407 \\
(23209)\end{array}$ & $\begin{array}{c}13779 \\
(1696)\end{array}$ & $\begin{array}{l}23760 \\
(4579)\end{array}$ & $\begin{array}{l}15680 \\
(3961)\end{array}$ \\
\hline Over 65 & $\begin{array}{l}107915 \\
(23875)\end{array}$ & $\begin{array}{c}91998 \\
(21947)\end{array}$ & $\begin{array}{l}102917 \\
(27022)\end{array}$ & $\begin{array}{r}13590 \\
(2112)\end{array}$ & $\begin{array}{l}20370 \\
(4655)\end{array}$ & $\begin{array}{l}14550 \\
(4314)\end{array}$ \\
\hline $\begin{array}{l}\text { All } \\
\text { Cohorts }\end{array}$ & $\begin{array}{l}57816 \\
(8793) \\
\end{array}$ & $\begin{array}{r}63350 \\
(7333) \\
\end{array}$ & $\begin{array}{r}70028 \\
(6515) \\
\end{array}$ & $\begin{array}{r}7599 \\
(410) \\
\end{array}$ & $\begin{array}{l}9279 \\
(731) \\
\end{array}$ & $\begin{array}{l}9779 \\
(604) \\
\end{array}$ \\
\hline $\begin{array}{l}\text { Notes: } \\
\text { All doll } \\
\text { Age 'n' }\end{array}$ & 1 & $f$ th $C$ & of $\mathrm{Co}$ & Fin & $\begin{array}{l}83,19 \\
\text { listed }\end{array}$ & $\begin{array}{l}1992 . \\
\text { ntheses. } \\
\text { year. }\end{array}$ \\
\hline
\end{tabular}




\begin{tabular}{|c|c|c|c|}
\hline \multicolumn{4}{|c|}{$\begin{array}{c}\text { Table } 4 \\
\text { Ownership and Allocation of Net Worth for All Households, by Year }\end{array}$} \\
\hline Wealth Component & 1983 & 1989 & 1992 \\
\hline & \multicolumn{3}{|c|}{ Probability of Ownership } \\
\hline Financial Assets & 89.79 & 87.56 & 88.95 \\
\hline Financial Debt & 41.12 & 40.90 & 41.33 \\
\hline Owner Occupied Assets & 63.41 & 64.72 & 63.93 \\
\hline Owner Occupied Debt & 36.94 & 39.55 & 39.03 \\
\hline Other Real Estate Assets & 21.00 & 20.40 & 19.35 \\
\hline Other Real Estate Debt & 8.19 & 6.97 & 7.72 \\
\hline Business Net Worth & 14.22 & 10.89 & 11.31 \\
\hline Miscellaneous Assets & 85.34 & 85.53 & 87.51 \\
\hline \multirow[t]{2}{*}{ Miscellaneous Debt } & 48.17 & 51.72 & 45.41 \\
\hline & \multicolumn{3}{|c|}{ Average Share of Household Total Assets } \\
\hline Financial Assets & 28.84 & 26.98 & 27.88 \\
\hline Financial Debt & 9.25 & 4.54 & 10.44 \\
\hline Owner Occupied Assets & 40.24 & 41.22 & 40.51 \\
\hline Owner Occupied Debt & 10.31 & 11.70 & 13.13 \\
\hline Other Real Estate Assets & 6.80 & 6.31 & 5.46 \\
\hline Other Real Estate Debt & 1.29 & 0.97 & 1.08 \\
\hline Business Net Worth & 4.72 & 3.52 & 3.79 \\
\hline Miscellaneous Assets & 19.39 & 21.97 & 22.35 \\
\hline \multirow[t]{2}{*}{ Miscellaneous Debt } & 18.83 & 36.16 & 22.63 \\
\hline & \multicolumn{3}{|c|}{ Share of Aggregate Household Total Assets } \\
\hline Financial Assets & 29.65 & 26.70 & 30.02 \\
\hline Financial Debt & 0.60 & 0.53 & 0.56 \\
\hline Owner Occupied Assets & 31.45 & 33.59 & 32.96 \\
\hline Owner Occupied Debt & 7.31 & 8.92 & 10.66 \\
\hline Other Real Estate Assets & 15.18 & 15.72 & 14.62 \\
\hline Other Real Estate Debt & 2.73 & 3.90 & 3.25 \\
\hline Business Net Worth & 19.22 & 16.58 & 16.20 \\
\hline Miscellaneous Assets & 4.50 & 7.41 & 6.20 \\
\hline Miscellaneous Debt & 2.19 & 2.55 & 1.69 \\
\hline
\end{tabular}


Table 5

Ownership and Allocation of Net Worth for Households Over Age 65, by Year

\begin{tabular}{|c|c|c|c|}
\hline Wealth Component & 1983 & 1989 & 1992 \\
\hline & \multicolumn{3}{|c|}{ Probability of Ownership } \\
\hline Financial Assets & 88.73 & 91.96 & 91.19 \\
\hline Financial Debt & 13.20 & 17.54 & 23.65 \\
\hline Owner Occupied Assets & 74.56 & 77.18 & 77.68 \\
\hline Owner Occupied Debt & 10.24 & 14.05 & 11.60 \\
\hline Other Real Estate Assets & 23.17 & 20.58 & 20.49 \\
\hline Other Real Estate Debt & 2.93 & 2.03 & 2.47 \\
\hline Business Net Worth & 9.45 & 5.35 & 6.03 \\
\hline Miscellaneous Assets & 71.46 & 77.03 & 80.84 \\
\hline \multirow[t]{2}{*}{ Miscellaneous Debt } & 13.05 & 16.91 & 17.52 \\
\hline & \multicolumn{3}{|c|}{ Average Share of Household Total Assets } \\
\hline Financial Assets & 37.22 & 36.20 & 34.76 \\
\hline Financial Debt & 15.73 & 1.38 & 1.73 \\
\hline Owner Occupied Assets & 44.90 & 46.23 & 47.62 \\
\hline Owner Occupied Debt & 1.86 & 2.05 & 2.07 \\
\hline Other Real Estate Assets & 6.94 & 4.90 & 5.15 \\
\hline Other Real Estate Debt & 0.18 & 0.15 & 0.25 \\
\hline Business Net Worth & 3.34 & 1.41 & 1.92 \\
\hline Miscellaneous Assets & 7.60 & 11.26 & 10.55 \\
\hline \multirow[t]{2}{*}{ Miscellaneous Debt } & 1.71 & 4.85 & 2.20 \\
\hline & \multicolumn{3}{|c|}{ Share of Aggregate Household Total Assets } \\
\hline Financial Assets & 41.56 & 38.29 & 37.99 \\
\hline Financial Debt & 0.12 & 0.20 & 0.30 \\
\hline Owner Occupied Assets & 24.26 & 30.12 & 28.78 \\
\hline Owner Occupied Debt & 0.99 & 1.02 & 1.36 \\
\hline Other Real Estate Assets & 17.21 & 14.45 & 16.59 \\
\hline Other Real Estate Debt & 0.86 & 1.44 & 1.49 \\
\hline Business Net Worth & 14.88 & 11.76 & 12.18 \\
\hline Miscellaneous Assets & 2.10 & 5.38 & 4.46 \\
\hline Miscellaneous Debt & 0.96 & 0.62 & 0.73 \\
\hline
\end{tabular}




\begin{tabular}{|c|c|c|c|c|c|c|}
\hline \multicolumn{7}{|c|}{$\begin{array}{c}\text { Table } 6 \\
\text { Net Worth Holdings by Cohort and Year }\end{array}$} \\
\hline \multirow{2}{*}{$\begin{array}{l}\text { Age } \\
\text { in } 1983\end{array}$} & \multicolumn{3}{|c|}{ Mean } & \multicolumn{3}{|c|}{ Median } \\
\hline & 1983 & 1989 & 1992 & 1983 & 1989 & 1992 \\
\hline 19 & $\begin{array}{l}12692 \\
(5649)\end{array}$ & $\begin{array}{c}34429 \\
(11141)\end{array}$ & $\begin{array}{c}43027 \\
(19119)\end{array}$ & $\begin{array}{c}3559 \\
(1098)\end{array}$ & $\begin{array}{c}3640 \\
(2388)\end{array}$ & $\begin{array}{l}10600 \\
(2828)\end{array}$ \\
\hline 22 & $\begin{array}{l}15591 \\
(3131)\end{array}$ & $\begin{array}{c}68203 \\
(32811)\end{array}$ & $\begin{array}{c}64151 \\
(15314)\end{array}$ & $\begin{array}{l}3000 \\
(766)\end{array}$ & $\begin{array}{l}15050 \\
(3854)\end{array}$ & $\begin{array}{l}21549 \\
(4782)\end{array}$ \\
\hline 25 & $\begin{array}{l}27048 \\
(6452)\end{array}$ & $\begin{array}{c}67639 \\
(15942)\end{array}$ & $\begin{array}{c}83892 \\
(18289)\end{array}$ & $\begin{array}{c}7059 \\
(1489)\end{array}$ & $\begin{array}{l}10979 \\
(5051)\end{array}$ & $\begin{array}{l}28409 \\
(5047)\end{array}$ \\
\hline 28 & $\begin{array}{l}34061 \\
(4402)\end{array}$ & $\begin{array}{c}89351 \\
(38760)\end{array}$ & $\begin{array}{l}113924 \\
(69959)\end{array}$ & $\begin{array}{l}10659 \\
(2017)\end{array}$ & $\begin{array}{l}22309 \\
(4235)\end{array}$ & $\begin{array}{l}29270 \\
(4662)\end{array}$ \\
\hline 31 & $\begin{array}{c}59174 \\
(40199)\end{array}$ & $\begin{array}{l}146219 \\
(39610)\end{array}$ & $\begin{array}{l}121372 \\
(35501)\end{array}$ & $\begin{array}{l}16319 \\
(3721)\end{array}$ & $\begin{array}{c}59759 \\
(10252)\end{array}$ & $\begin{array}{l}50799 \\
(6366)\end{array}$ \\
\hline 34 & $\begin{array}{l}102608 \\
(22971)\end{array}$ & $\begin{array}{l}149136 \\
(83200)\end{array}$ & $\begin{array}{l}174983 \\
(47394)\end{array}$ & $\begin{array}{l}46520 \\
(5652)\end{array}$ & $\begin{array}{c}70769 \\
(10452)\end{array}$ & $\begin{array}{c}66400 \\
(12066)\end{array}$ \\
\hline 37 & $\begin{array}{l}122283 \\
(52928)\end{array}$ & $\begin{array}{l}229282 \\
(94758)\end{array}$ & $\begin{array}{l}201460 \\
(51784)\end{array}$ & $\begin{array}{l}49299 \\
(5246)\end{array}$ & $\begin{array}{l}79199 \\
(8980)\end{array}$ & $\begin{array}{l}54049 \\
(9941)\end{array}$ \\
\hline 40 & $\begin{array}{r}125330 \\
(15902)\end{array}$ & $\begin{array}{l}261377 \\
(91228)\end{array}$ & $\begin{array}{l}252401 \\
(88956)\end{array}$ & $\begin{array}{l}56450 \\
(5006)\end{array}$ & $\begin{array}{c}86330 \\
(16034)\end{array}$ & $\begin{array}{c}81300 \\
(10276)\end{array}$ \\
\hline 43 & $\begin{array}{l}139495 \\
(21681)\end{array}$ & $\begin{array}{l}275855 \\
(87207)\end{array}$ & $\begin{array}{l}300262 \\
(78445)\end{array}$ & $\begin{array}{c}66849 \\
(11430)\end{array}$ & $\begin{array}{l}104989 \\
(19541)\end{array}$ & $\begin{array}{c}98500 \\
(20739)\end{array}$ \\
\hline 46 & $\begin{array}{c}262211 \\
(125622)\end{array}$ & $\begin{array}{c}337379 \\
(156663)\end{array}$ & $\begin{array}{l}316458 \\
(74703)\end{array}$ & $\begin{array}{c}90389 \\
(15178)\end{array}$ & $\begin{array}{l}106129 \\
(26894)\end{array}$ & $\begin{array}{l}127230 \\
(16171)\end{array}$ \\
\hline 49 & $\begin{array}{l}270937 \\
(79596)\end{array}$ & $\begin{array}{c}279117 \\
(103127)\end{array}$ & $\begin{array}{c}357069 \\
(121208)\end{array}$ & $\begin{array}{l}75779 \\
(8888)\end{array}$ & $\begin{array}{l}101809 \\
(15255)\end{array}$ & $\begin{array}{l}133300 \\
(18553)\end{array}$ \\
\hline 52 & $\begin{array}{l}203575 \\
(43348)\end{array}$ & $\begin{array}{c}293317 \\
(125381)\end{array}$ & $\begin{array}{c}358761 \\
(128429)\end{array}$ & $\begin{array}{l}91790 \\
(9962)\end{array}$ & $\begin{array}{l}111500 \\
(15658)\end{array}$ & $\begin{array}{l}130679 \\
(21685)\end{array}$ \\
\hline 55 & $\begin{array}{c}269377 \\
(118305)\end{array}$ & $\begin{array}{c}335652 \\
(101528)\end{array}$ & $\begin{array}{c}256498 \\
(104563)\end{array}$ & $\begin{array}{c}88760 \\
(16018)\end{array}$ & $\begin{array}{c}95610 \\
(20020)\end{array}$ & $\begin{array}{c}82099 \\
(17159)\end{array}$ \\
\hline 58 & $\begin{array}{l}292612 \\
(62470)\end{array}$ & $\begin{array}{c}344166 \\
(205060)\end{array}$ & $\begin{array}{c}277621 \\
(131290)\end{array}$ & $\begin{array}{l}107059 \\
(15831)\end{array}$ & $\begin{array}{l}111050 \\
(28337)\end{array}$ & $\begin{array}{c}87419 \\
(18390)\end{array}$ \\
\hline
\end{tabular}




\begin{tabular}{|c|c|c|c|c|c|c|}
\hline \multirow{2}{*}{$\begin{array}{l}\text { Age in } \\
1983\end{array}$} & \multicolumn{3}{|c|}{ Mean } & \multicolumn{3}{|c|}{ Median } \\
\hline & 1983 & 1989 & 1992 & 1983 & 1989 & 1992 \\
\hline 61 & $\begin{array}{c}299167 \\
(109138)\end{array}$ & $\begin{array}{c}299373 \\
(143490)\end{array}$ & $\begin{array}{c}296988 \\
(157152)\end{array}$ & $\begin{array}{l}127029 \\
(14171)\end{array}$ & $\begin{array}{c}70150 \\
(12058)\end{array}$ & $\begin{array}{l}103440 \\
(19882)\end{array}$ \\
\hline 64 & $\begin{array}{c}348270 \\
(108733)\end{array}$ & $\begin{array}{c}298177 \\
(134406)\end{array}$ & $\begin{array}{c}257417 \\
(147107)\end{array}$ & $\begin{array}{c}86269 \\
(11060)\end{array}$ & $\begin{array}{l}105230 \\
(15693)\end{array}$ & $\begin{array}{c}97529 \\
(15454)\end{array}$ \\
\hline 67 & $\begin{array}{c}364771 \\
(132656)\end{array}$ & $\begin{array}{c}236069 \\
(116156)\end{array}$ & $\begin{array}{l}217193 \\
(64389)\end{array}$ & $\begin{array}{c}98059 \\
(15804)\end{array}$ & $\begin{array}{c}99569 \\
(18400)\end{array}$ & $\begin{array}{l}117949 \\
(24983)\end{array}$ \\
\hline 70 & $\begin{array}{l}300125 \\
(94164)\end{array}$ & $\begin{array}{l}243804 \\
(60066)\end{array}$ & $\begin{array}{c}259474 \\
(181154)\end{array}$ & $\begin{array}{c}90400 \\
(10955)\end{array}$ & $\begin{array}{l}111260 \\
(28769)\end{array}$ & $\begin{array}{c}88500 \\
(11196)\end{array}$ \\
\hline 73 & $\begin{array}{l}240507 \\
(74403)\end{array}$ & $\begin{array}{c}176476 \\
(181932)\end{array}$ & $\begin{array}{r}168679 \\
(53405)\end{array}$ & $\begin{array}{c}73470 \\
(11117)\end{array}$ & $\begin{array}{c}49779 \\
(15495)\end{array}$ & $\begin{array}{c}42700 \\
(26263)\end{array}$ \\
\hline 76 & $\begin{array}{l}167327 \\
(82805)\end{array}$ & $\begin{array}{c}209846 \\
(117350)\end{array}$ & $\begin{array}{c}213156 \\
(134761)\end{array}$ & $\begin{array}{c}62520 \\
(19669)\end{array}$ & $\begin{array}{c}100699 \\
(16965)\end{array}$ & $\begin{array}{c}70699 \\
(11343)\end{array}$ \\
\hline 79 & $\begin{array}{r}203574 \\
(89658) \\
\end{array}$ & $\begin{array}{c}126895 \\
(101769) \\
\end{array}$ & $\begin{array}{c}230709 \\
(198478) \\
\end{array}$ & $\begin{array}{l}73150 \\
(7946) \\
\end{array}$ & $\begin{array}{c}49439 \\
(10348) \\
\end{array}$ & $\begin{array}{c}86099 \\
(41080) \\
\end{array}$ \\
\hline Over 62 & $\begin{array}{l}269486 \\
(39448)\end{array}$ & $\begin{array}{l}232101 \\
(53797)\end{array}$ & $\begin{array}{l}229822 \\
(57221)\end{array}$ & $\begin{array}{l}77480 \\
(4059)\end{array}$ & $\begin{array}{l}95949 \\
(8308)\end{array}$ & $\begin{array}{l}86900 \\
(6450)\end{array}$ \\
\hline Over 65 & $\begin{array}{l}252104 \\
(41520)\end{array}$ & $\begin{array}{l}214407 \\
(57636)\end{array}$ & $\begin{array}{l}221141 \\
(57954)\end{array}$ & $\begin{array}{l}74559 \\
(4493)\end{array}$ & $\begin{array}{c}87120 \\
(10296)\end{array}$ & $\begin{array}{l}86599 \\
(6978)\end{array}$ \\
\hline $\begin{array}{l}\text { All } \\
\text { Cohorts }\end{array}$ & $\begin{array}{r}173635 \\
(15521) \\
\end{array}$ & $\begin{array}{l}200471 \\
(22721) \\
\end{array}$ & $\begin{array}{r}195375 \\
(18602) \\
\end{array}$ & $\begin{array}{l}51919 \\
(1802) \\
\end{array}$ & $\begin{array}{l}62229 \\
(4040) \\
\end{array}$ & $\begin{array}{r}58400 \\
(2278) \\
\end{array}$ \\
\hline
\end{tabular}




\begin{tabular}{|c|c|c|c|c|c|c|}
\hline \multicolumn{7}{|c|}{$\begin{array}{c}\text { Table } 7 \\
\text { Total Asset Holdings by Cohort and Year }\end{array}$} \\
\hline \multirow{2}{*}{$\begin{array}{l}\text { Age } \\
\text { in } 1983\end{array}$} & \multicolumn{3}{|c|}{ Mean } & \multicolumn{3}{|c|}{ Median } \\
\hline & 1983 & 1989 & 1992 & 1983 & 1989 & 1992 \\
\hline 19 & $\begin{array}{l}15636 \\
(6325)\end{array}$ & $\begin{array}{c}53596 \\
(13109)\end{array}$ & $\begin{array}{c}70036 \\
(20843)\end{array}$ & $\begin{array}{c}3659 \\
(1459)\end{array}$ & $\begin{array}{c}9850 \\
(2513)\end{array}$ & $\begin{array}{l}18739 \\
(4677)\end{array}$ \\
\hline 22 & $\begin{array}{l}21769 \\
(3786)\end{array}$ & $\begin{array}{c}98828 \\
(33690)\end{array}$ & $\begin{array}{l}109249 \\
(17147)\end{array}$ & $\begin{array}{l}5849 \\
(880)\end{array}$ & $\begin{array}{l}23079 \\
(5635)\end{array}$ & $\begin{array}{l}39979 \\
(9607)\end{array}$ \\
\hline 25 & $\begin{array}{l}42212 \\
(6748)\end{array}$ & $\begin{array}{l}107443 \\
(18116)\end{array}$ & $\begin{array}{l}124134 \\
(23368)\end{array}$ & $\begin{array}{l}11669 \\
(2231)\end{array}$ & $\begin{array}{c}26290 \\
(13226)\end{array}$ & $\begin{array}{c}52130 \\
(11154)\end{array}$ \\
\hline 28 & $\begin{array}{l}53550 \\
(5178)\end{array}$ & $\begin{array}{l}137356 \\
(40134)\end{array}$ & $\begin{array}{l}159089 \\
(70784)\end{array}$ & $\begin{array}{l}20579 \\
(4426)\end{array}$ & $\begin{array}{c}57700 \\
(10819)\end{array}$ & $\begin{array}{c}61349 \\
(14089)\end{array}$ \\
\hline 31 & $\begin{array}{c}82974 \\
(40298)\end{array}$ & $\begin{array}{l}202935 \\
(43300)\end{array}$ & $\begin{array}{l}170710 \\
(36822)\end{array}$ & $\begin{array}{l}29810 \\
(7611)\end{array}$ & $\begin{array}{r}102169 \\
(14377)\end{array}$ & $\begin{array}{l}104000 \\
(11752)\end{array}$ \\
\hline 34 & $\begin{array}{l}142963 \\
(23705)\end{array}$ & $\begin{array}{l}199395 \\
(86787)\end{array}$ & $\begin{array}{l}226656 \\
(50520)\end{array}$ & $\begin{array}{l}80889 \\
(8279)\end{array}$ & $\begin{array}{l}113470 \\
(16955)\end{array}$ & $\begin{array}{l}104569 \\
(12681)\end{array}$ \\
\hline 37 & $\begin{array}{l}166289 \\
(53537)\end{array}$ & $\begin{array}{c}309543 \\
(134137)\end{array}$ & $\begin{array}{l}254761 \\
(58159)\end{array}$ & $\begin{array}{l}94939 \\
(7184)\end{array}$ & $\begin{array}{l}132600 \\
(15396)\end{array}$ & $\begin{array}{r}103750 \\
(15476)\end{array}$ \\
\hline 40 & $\begin{array}{l}165970 \\
(19237)\end{array}$ & $\begin{array}{c}329990 \\
(106255)\end{array}$ & $\begin{array}{l}315472 \\
(92122)\end{array}$ & $\begin{array}{l}96529 \\
(10598)\end{array}$ & $\begin{array}{l}125729 \\
(25017)\end{array}$ & $\begin{array}{l}115099 \\
(17200)\end{array}$ \\
\hline 43 & $\begin{array}{c}179442 \\
(179442)\end{array}$ & $\begin{array}{l}323463 \\
(95543)\end{array}$ & $\begin{array}{l}349924 \\
(83774)\end{array}$ & $\begin{array}{l}101419 \\
(11625)\end{array}$ & $\begin{array}{l}132139 \\
(22972)\end{array}$ & $\begin{array}{l}127449 \\
(23158)\end{array}$ \\
\hline 46 & $\begin{array}{c}299935 \\
(126825)\end{array}$ & $\begin{array}{c}379894 \\
(163085)\end{array}$ & $\begin{array}{l}355593 \\
(80892)\end{array}$ & $\begin{array}{l}129039 \\
(14325)\end{array}$ & $\begin{array}{l}139679 \\
(27332)\end{array}$ & $\begin{array}{l}139500 \\
(15927)\end{array}$ \\
\hline 49 & $\begin{array}{l}321129 \\
(95517)\end{array}$ & $\begin{array}{c}333108 \\
(118559)\end{array}$ & $\begin{array}{c}409372 \\
(127382)\end{array}$ & $\begin{array}{l}100950 \\
(12296)\end{array}$ & $\begin{array}{l}141679 \\
(21246)\end{array}$ & $\begin{array}{l}167649 \\
(27387)\end{array}$ \\
\hline 52 & $\begin{array}{l}228999 \\
(45437)\end{array}$ & $\begin{array}{c}335278 \\
(150167)\end{array}$ & $\begin{array}{c}390753 \\
(132970)\end{array}$ & $\begin{array}{l}115659 \\
(11052)\end{array}$ & $\begin{array}{l}130350 \\
(8948)\end{array}$ & $\begin{array}{l}154300 \\
(19170)\end{array}$ \\
\hline 55 & $\begin{array}{c}295926 \\
(121699)\end{array}$ & $\begin{array}{c}358332 \\
(108612)\end{array}$ & $\begin{array}{c}285804 \\
(116594)\end{array}$ & $\begin{array}{l}109519 \\
(16088)\end{array}$ & $\begin{array}{l}116180 \\
(21234)\end{array}$ & $\begin{array}{c}98099 \\
(20028)\end{array}$ \\
\hline 58 & $\begin{array}{l}325506 \\
(67749)\end{array}$ & $\begin{array}{c}370565 \\
(252822)\end{array}$ & $\begin{array}{c}300889 \\
(157531)\end{array}$ & $\begin{array}{l}137130 \\
(16816)\end{array}$ & $\begin{array}{l}114269 \\
(25345)\end{array}$ & $\begin{array}{c}87419 \\
(18237)\end{array}$ \\
\hline
\end{tabular}




\begin{tabular}{|c|c|c|c|c|c|c|}
\hline \multirow{2}{*}{$\begin{array}{l}\text { Age in } \\
1983\end{array}$} & \multicolumn{3}{|c|}{ Mean } & \multicolumn{3}{|c|}{ Median } \\
\hline & 1983 & 1989 & 1992 & 1983 & 1989 & 1992 \\
\hline 61 & $\begin{array}{c}320726 \\
(112048)\end{array}$ & $\begin{array}{c}310893 \\
(144862)\end{array}$ & $\begin{array}{c}303674 \\
(159057)\end{array}$ & $\begin{array}{l}135990 \\
(13551)\end{array}$ & $\begin{array}{c}76569 \\
(11751)\end{array}$ & $\begin{array}{l}104309 \\
(19695)\end{array}$ \\
\hline 64 & $\begin{array}{c}365917 \\
(113134)\end{array}$ & $\begin{array}{c}309283 \\
(167223)\end{array}$ & $\begin{array}{c}265967 \\
(163438)\end{array}$ & $\begin{array}{c}94500 \\
(16377)\end{array}$ & $\begin{array}{l}109750 \\
(13908)\end{array}$ & $\begin{array}{c}97529 \\
(15454)\end{array}$ \\
\hline 67 & $\begin{array}{c}377039 \\
(133288)\end{array}$ & $\begin{array}{c}252422 \\
(158361)\end{array}$ & $\begin{array}{l}227279 \\
(71180)\end{array}$ & $\begin{array}{c}98889 \\
(16141)\end{array}$ & $\begin{array}{c}99559 \\
(17574)\end{array}$ & $\begin{array}{l}125000 \\
(22511)\end{array}$ \\
\hline 70 & $\begin{array}{l}313354 \\
(96412)\end{array}$ & $\begin{array}{l}247760 \\
(60332)\end{array}$ & $\begin{array}{c}270004 \\
(184700)\end{array}$ & $\begin{array}{c}99269 \\
(15671)\end{array}$ & $\begin{array}{l}114260 \\
(24123)\end{array}$ & $\begin{array}{c}94349 \\
(18062)\end{array}$ \\
\hline 73 & $\begin{array}{l}244194 \\
(74801)\end{array}$ & $\begin{array}{c}180738 \\
(182536)\end{array}$ & $\begin{array}{l}169808 \\
(53484)\end{array}$ & $\begin{array}{c}74860 \\
(11125)\end{array}$ & $\begin{array}{c}50919 \\
(13914)\end{array}$ & $\begin{array}{c}42700 \\
(26263)\end{array}$ \\
\hline 76 & $\begin{array}{l}176245 \\
(85189)\end{array}$ & $\begin{array}{c}213574 \\
(118623)\end{array}$ & $\begin{array}{c}215686 \\
(142087)\end{array}$ & $\begin{array}{c}62510 \\
(19666)\end{array}$ & $\begin{array}{l}100699 \\
(14994)\end{array}$ & $\begin{array}{c}70699 \\
(11343)\end{array}$ \\
\hline 79 & $\begin{array}{l}206733 \\
(94511) \\
\end{array}$ & $\begin{array}{c}127208 \\
(101860) \\
\end{array}$ & $\begin{array}{r}234424 \\
(198466) \\
\end{array}$ & $\begin{array}{l}73150 \\
(7977) \\
\end{array}$ & $\begin{array}{c}49439 \\
(10342) \\
\end{array}$ & $\begin{array}{r}86099 \\
(45202) \\
\end{array}$ \\
\hline Over 62 & $\begin{array}{l}278894 \\
(40439)\end{array}$ & $\begin{array}{l}239619 \\
(61850)\end{array}$ & $\begin{array}{l}236992 \\
(61098)\end{array}$ & $\begin{array}{l}81000 \\
(4339)\end{array}$ & $\begin{array}{l}99559 \\
(9381)\end{array}$ & $\begin{array}{l}89579 \\
(7846)\end{array}$ \\
\hline Over 65 & $\begin{array}{l}259694 \\
(42317)\end{array}$ & $\begin{array}{l}220964 \\
(63727)\end{array}$ & $\begin{array}{l}227876 \\
(59865)\end{array}$ & $\begin{array}{l}77489 \\
(5122)\end{array}$ & $\begin{array}{l}87120 \\
(11123)\end{array}$ & $\begin{array}{l}88400 \\
(7821)\end{array}$ \\
\hline $\begin{array}{l}\text { All } \\
\text { Cohorts }\end{array}$ & $\begin{array}{l}200016 \\
(16102)\end{array}$ & $\begin{array}{l}238725 \\
(26070)\end{array}$ & $\begin{array}{l}232573 \\
(19935)\end{array}$ & $\begin{array}{l}73000 \\
(2213)\end{array}$ & $\begin{array}{l}91319 \\
(4728)\end{array}$ & $\begin{array}{l}88430 \\
(3467)\end{array}$ \\
\hline
\end{tabular}




\begin{tabular}{||l|cc||}
\hline \multicolumn{3}{||c||}{ Tests for Joint Significance of Cohort Effects in Ownership and Allocation } \\
\hline Financial Asset & Ownership Probits & Portfolio Share Tobits \\
\hline Taxable Equity & 0.0072 & 0.0134 \\
(Directly Held Only) & 0.1508 & 0.1555 \\
\hline Taxable Equity & 0.0000 & 0.0000 \\
Tax-Exempt Bonds & 0.0010 & 0.0001 \\
Taxable Bonds & 0.0000 & 0.0000 \\
Tax-Deferred Accts & 0.0006 & 0.0000 \\
Bank Accounts & 0.0750 & 0.0017 \\
Other Fin Assets & & \\
\hline $\begin{array}{l}\text { Notes: Authors' estimates from the SCFs 1983, 1989, and 1992. Joint significance tests } \\
\text { for probits are based on a chi-square distribution with 20 degrees of freedom. Joint } \\
\text { significance tests for Tobits are based on an F-distribution with 20 (numerator) and } 9759 \\
\text { (denominator) degrees of freedom. }\end{array}$ \\
\hline
\end{tabular}


Table 9

Tests for Joint Significance of Cohort Effects in Ownership and Allocation of Total Assets

Wealth Component

Financial Assets

Financial Debt

Owner Occupied Assets

Owner Occupied Debt

Other Real Estate Assets

Other Real Estate Debt

Business Net Worth

Miscellaneous Assets

Miscellaneous Debt
Ownership Probits

0.0018

0.0000

0.0005

0.0003

0.0484

0.3106

0.0001

0.0001

0.0071
Total Asset Share Tobits

0.0454

0.0000

0.0418

0.0000

0.0108

0.2804

0.0003

0.0000

0.0678

Notes: Authors' estimates from the SCFs 1983, 1989, and 1992. Joint significance tests for probits are based on a chi-square distribution with 20 degrees of freedom. Joint significance tests for Tobits are based on an F-distribution with 20 (numerator) and 10292 (denominator) degrees of freedom. 

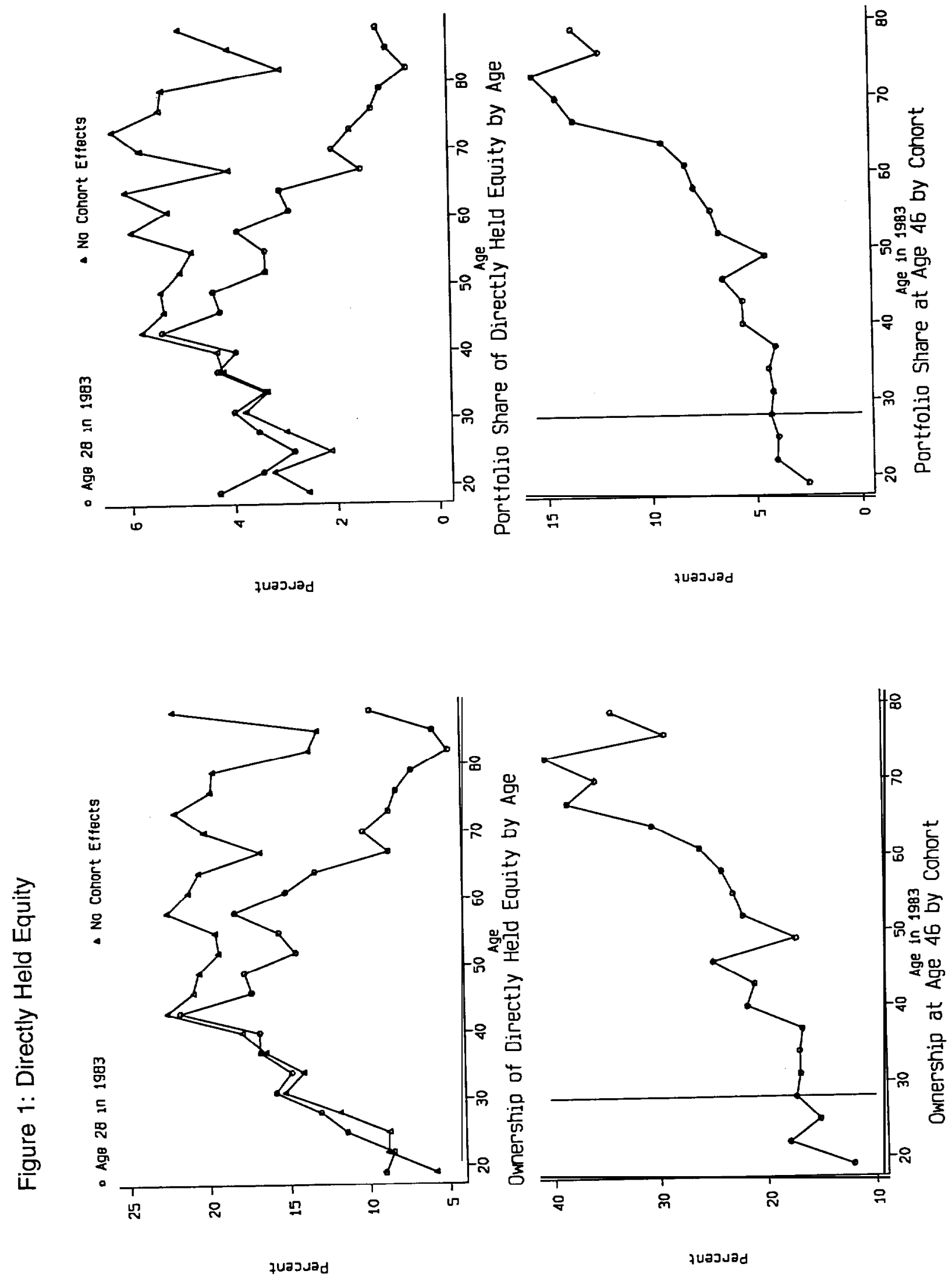


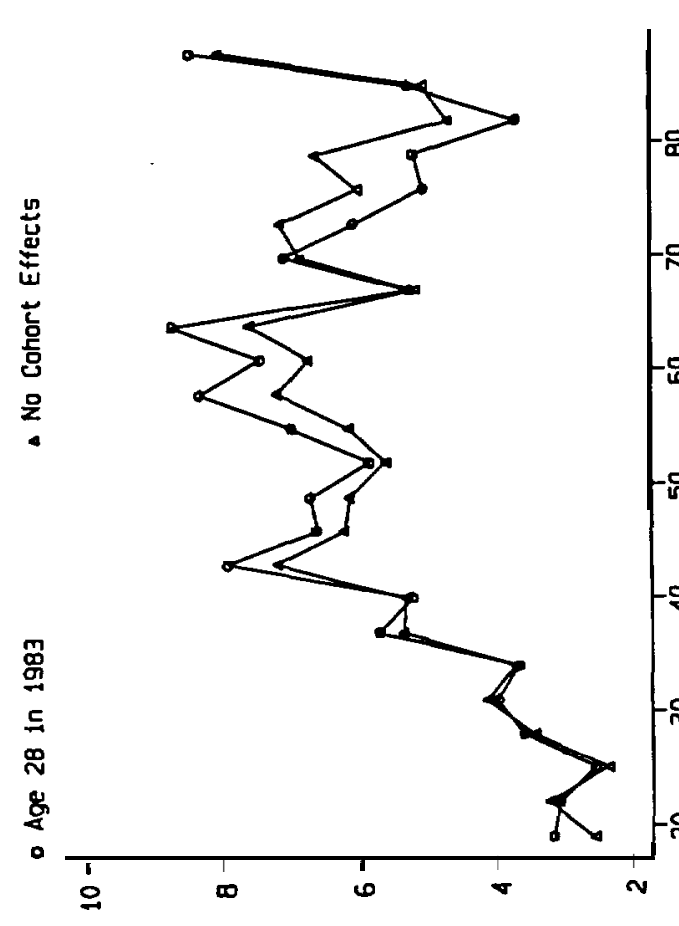

quassad

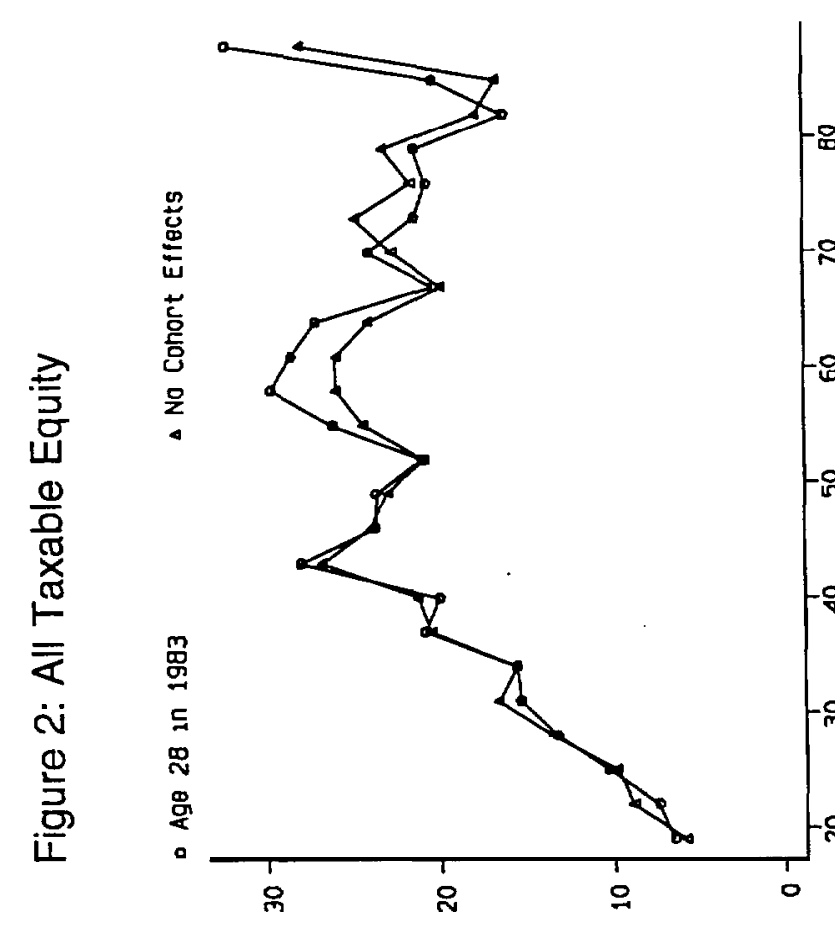

quasuad

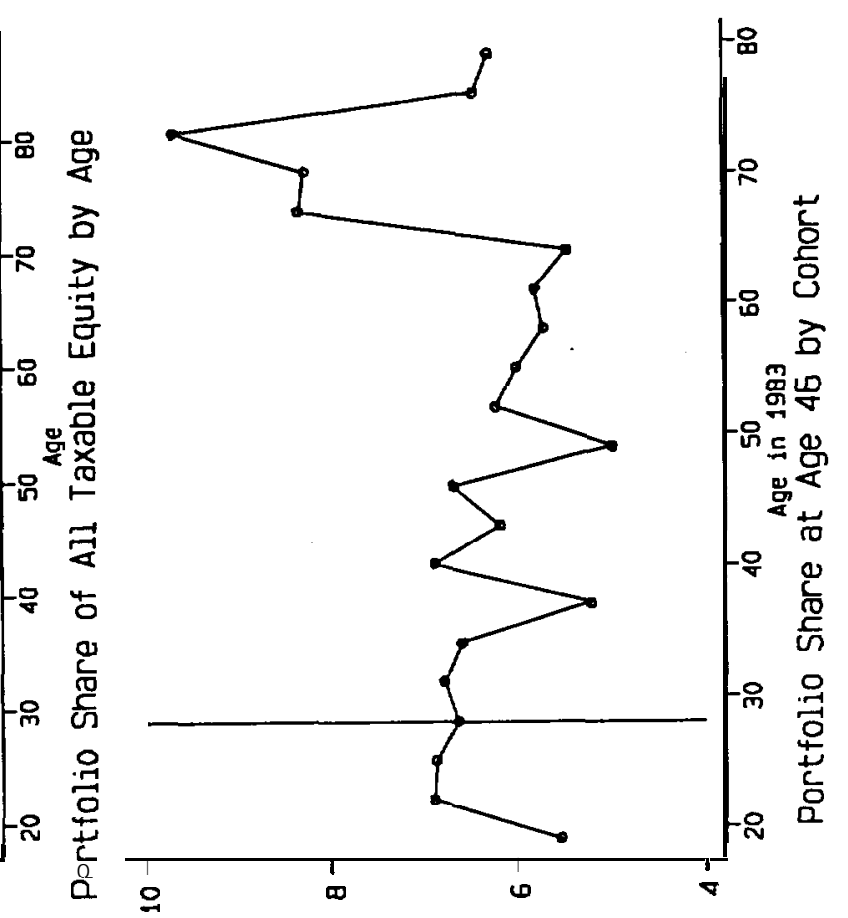

วบวכدаd

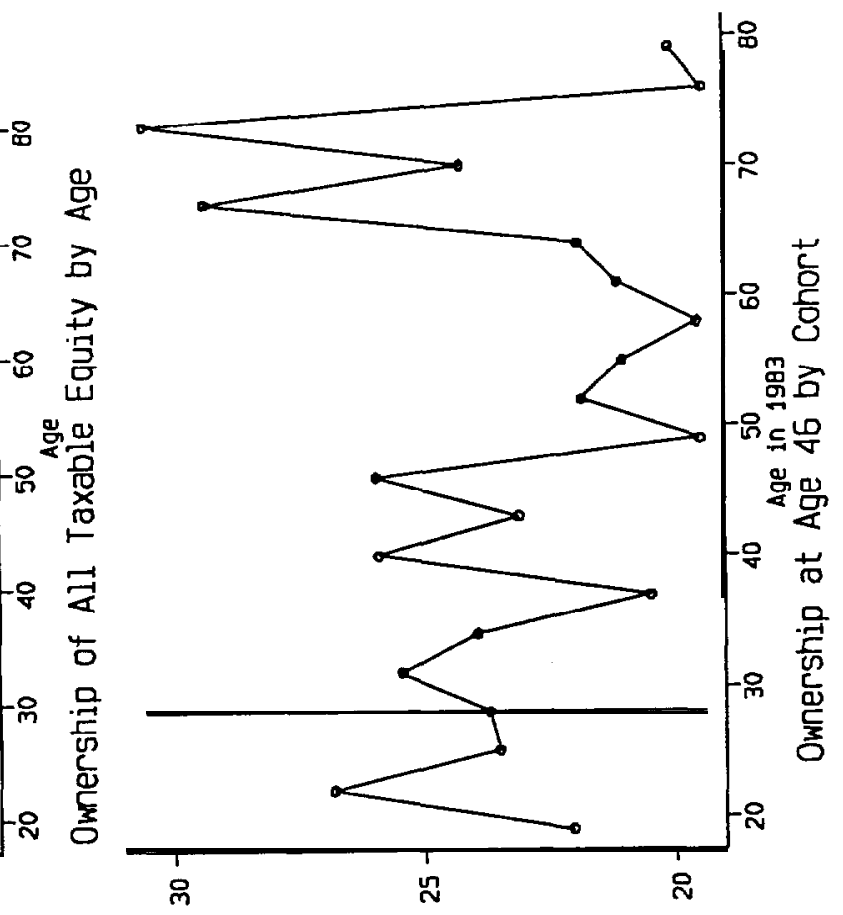

quaJjad 

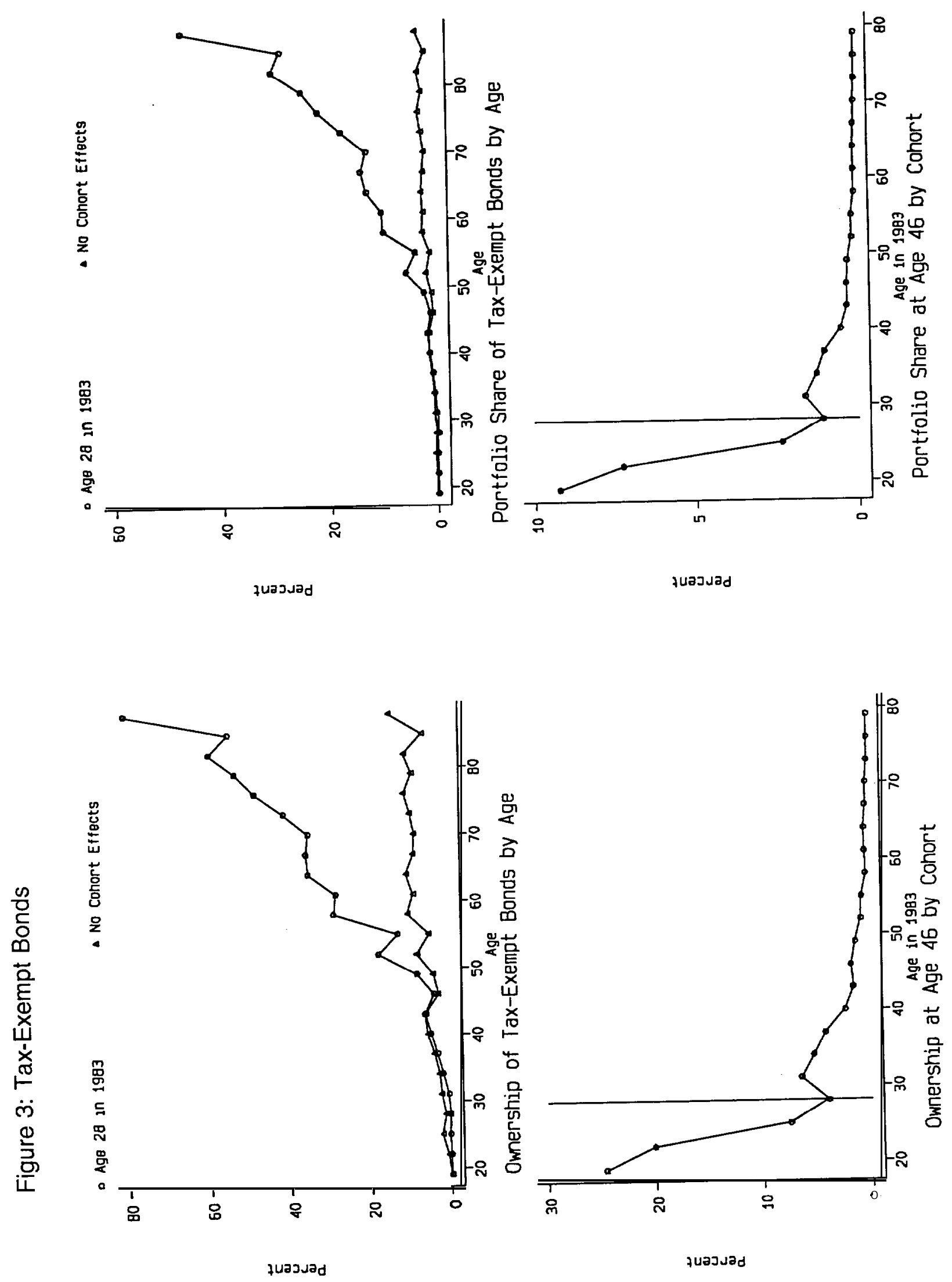

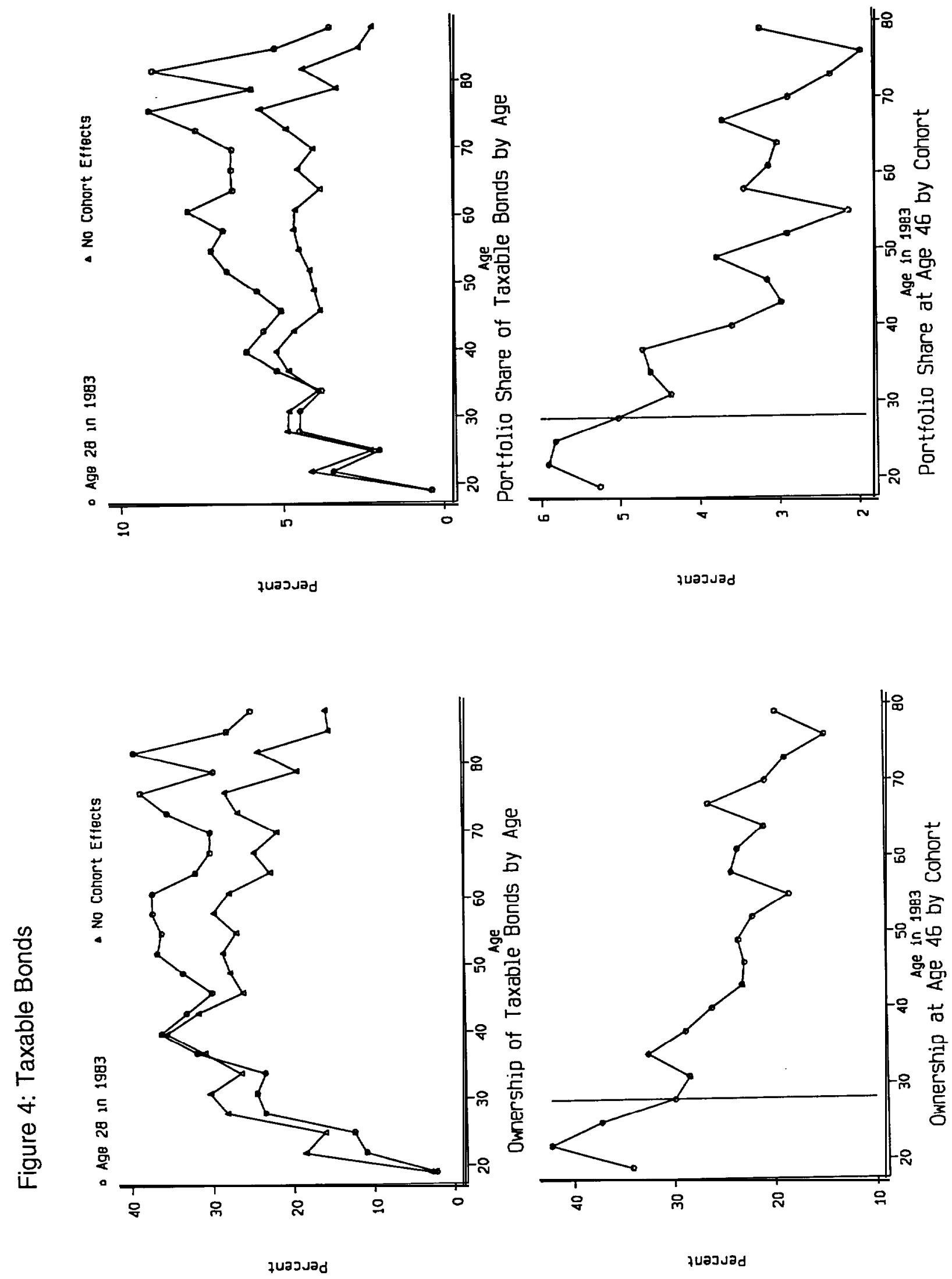

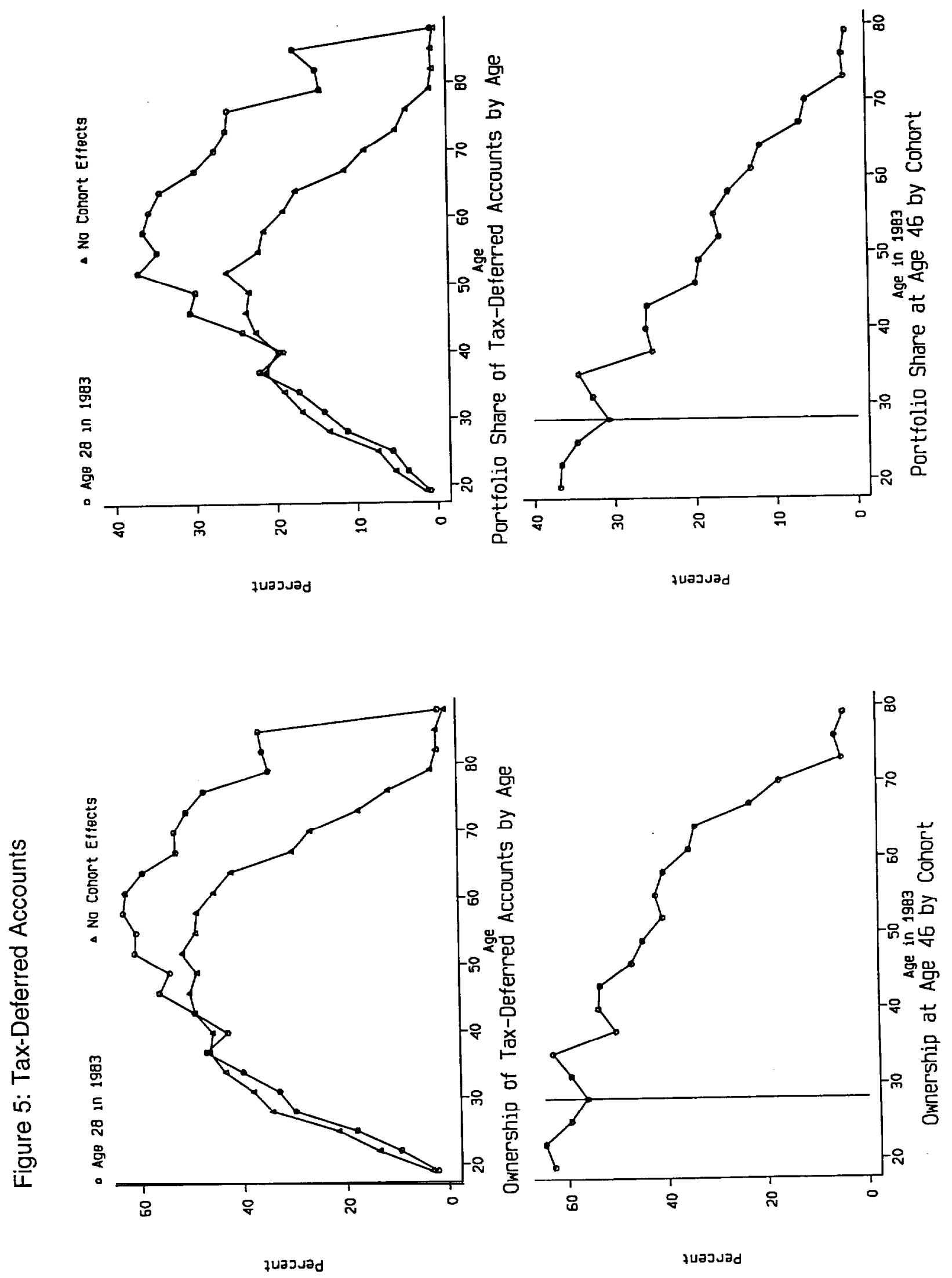

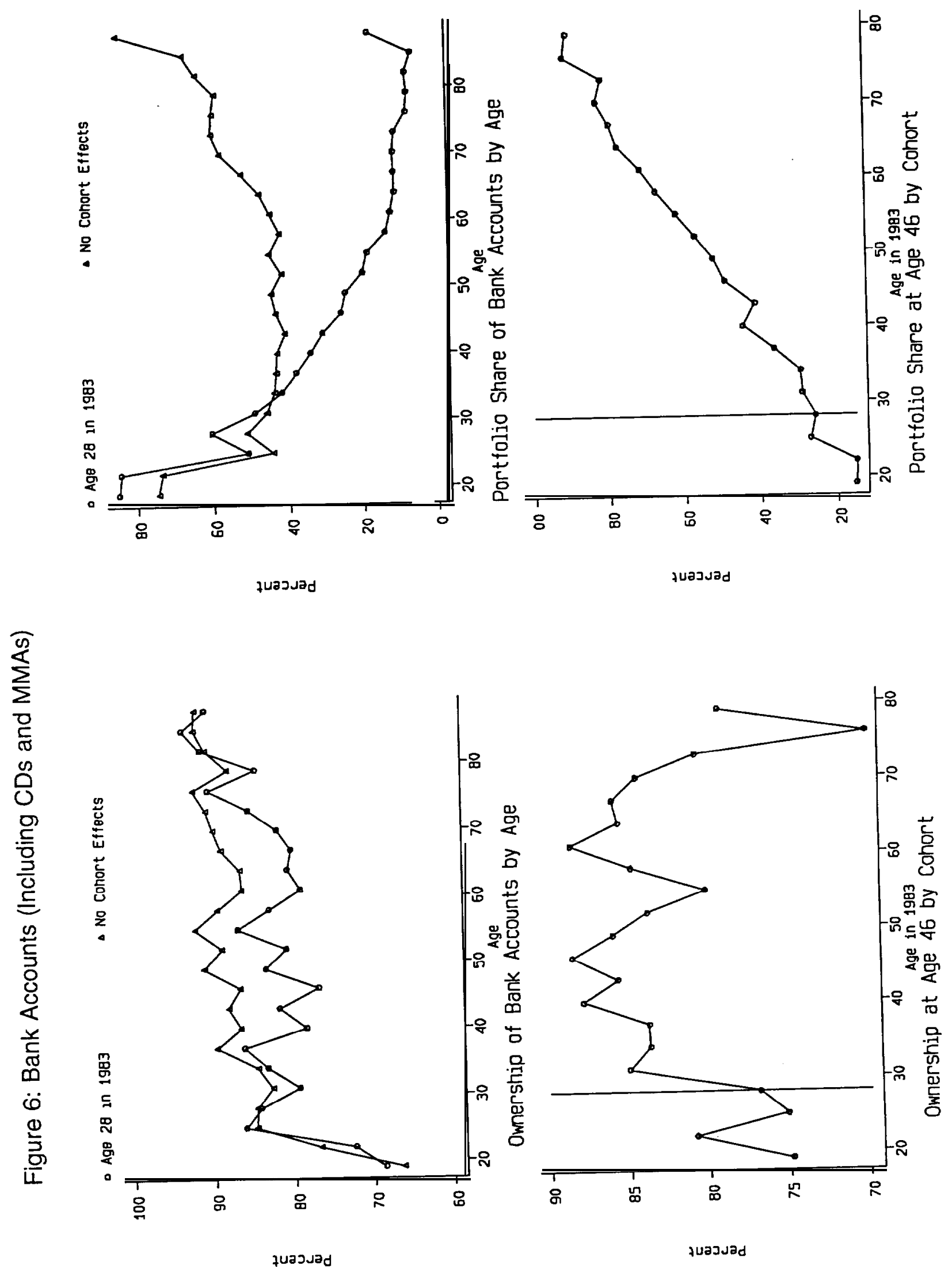

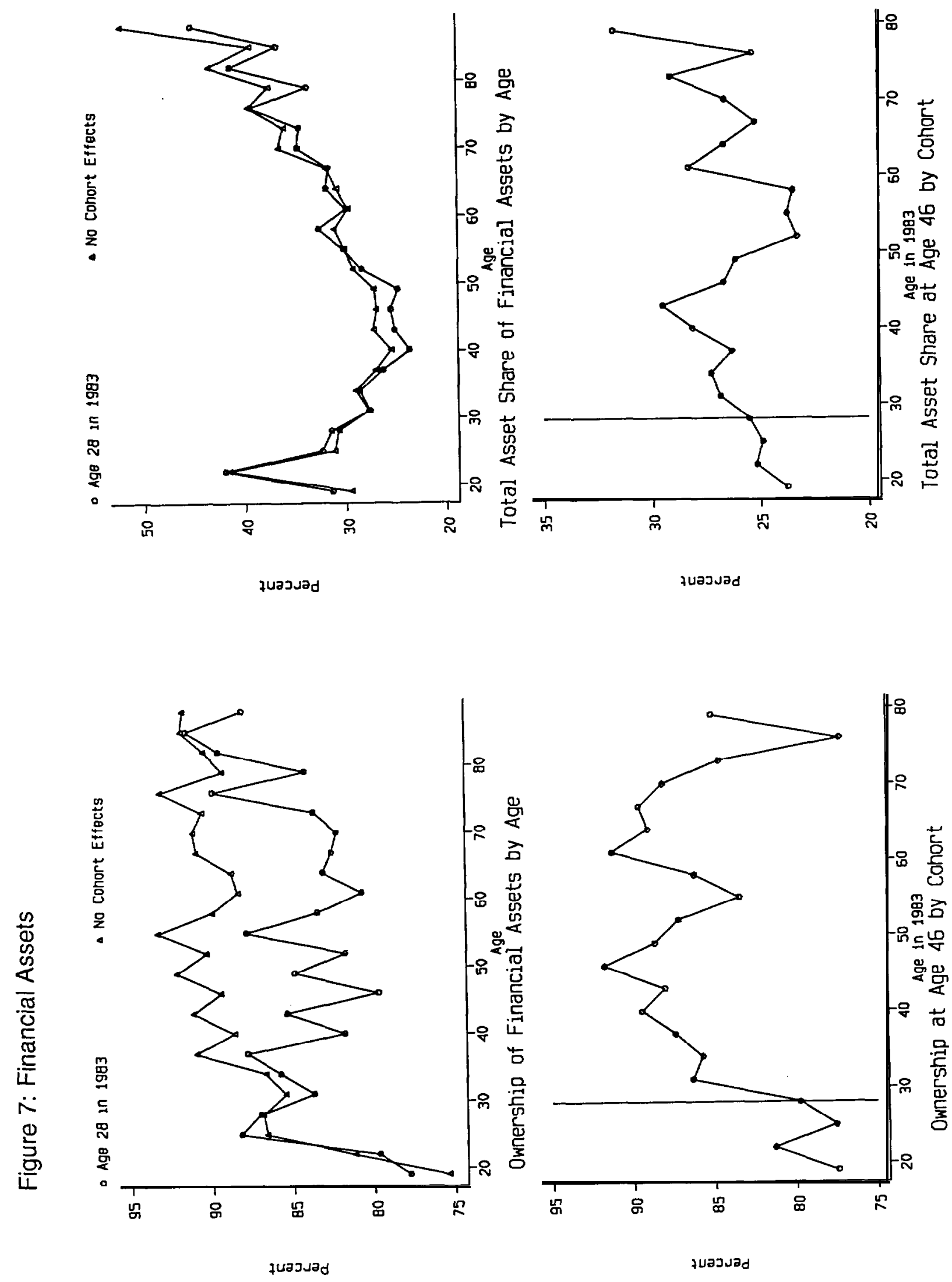
Figure 8: Financial Debt
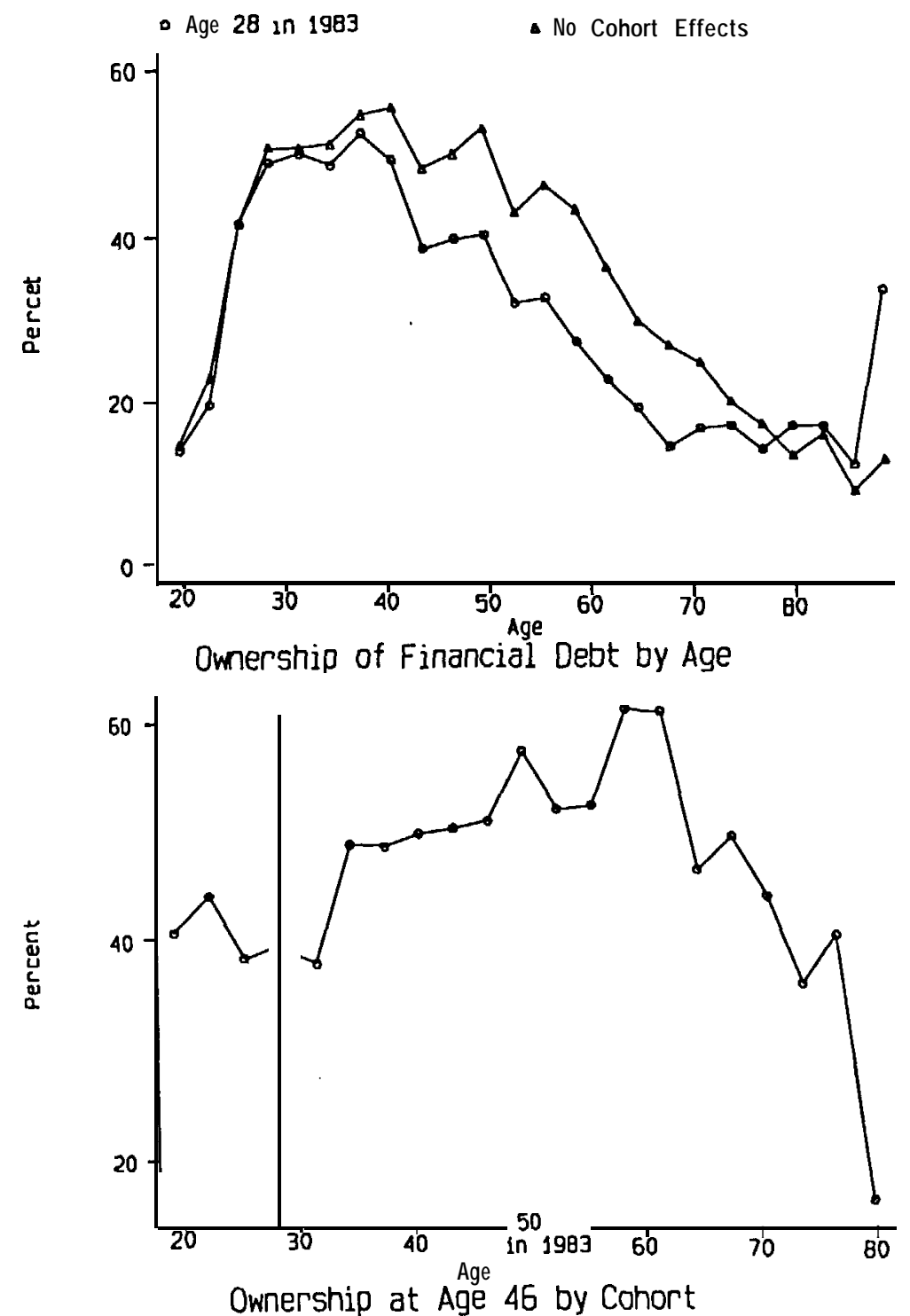

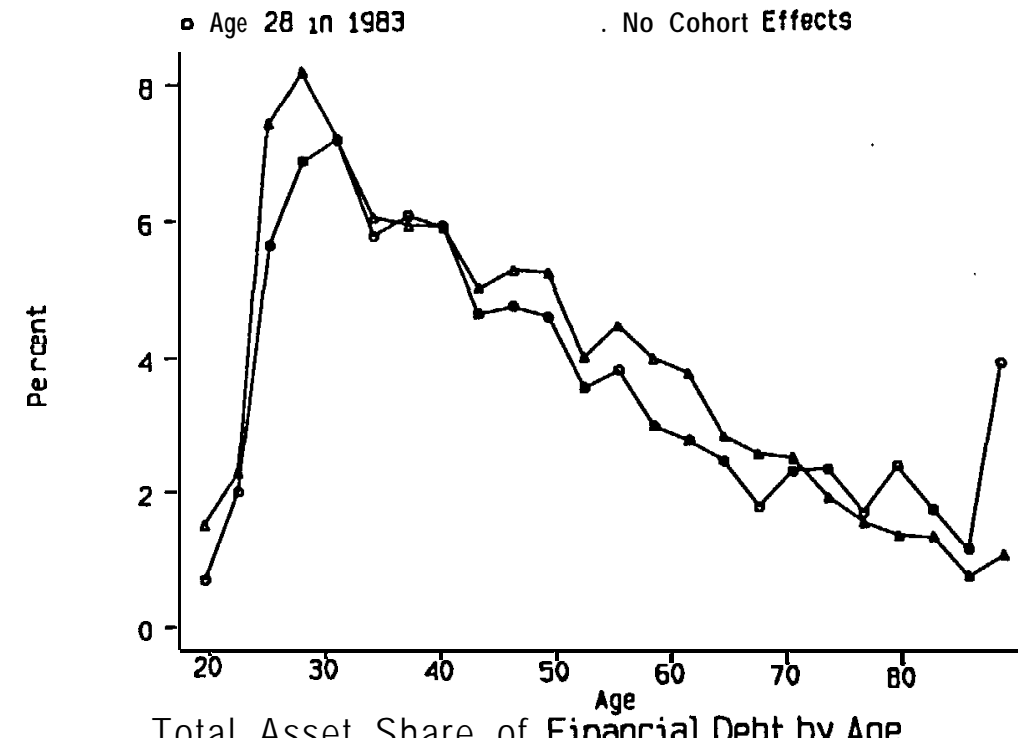

Total Asset Share of Financial Debt by Age

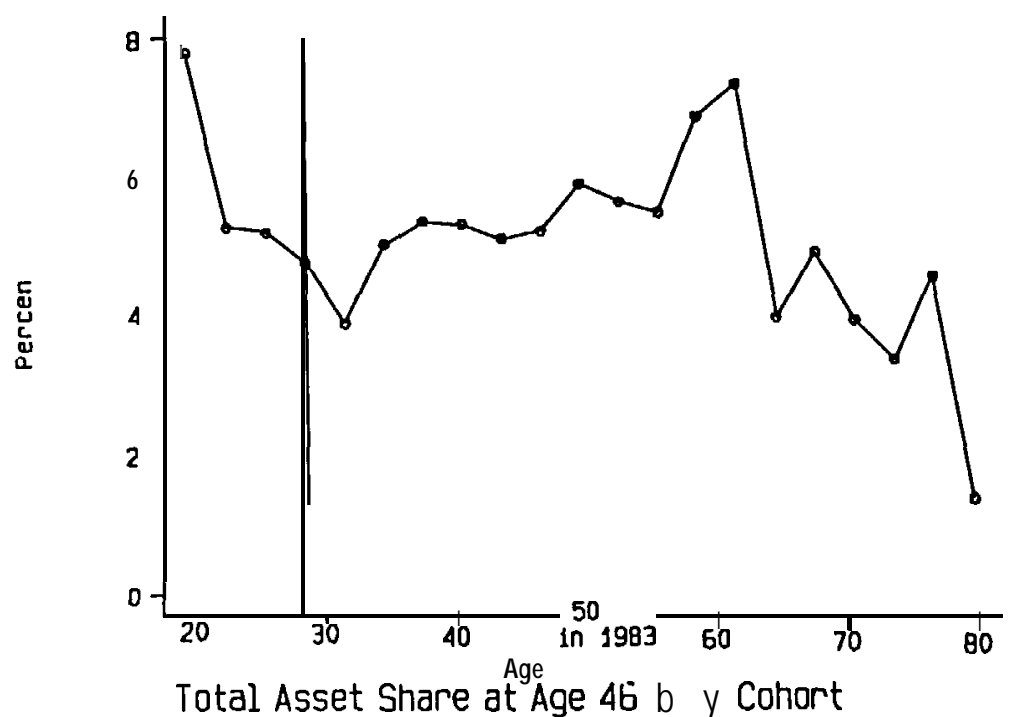



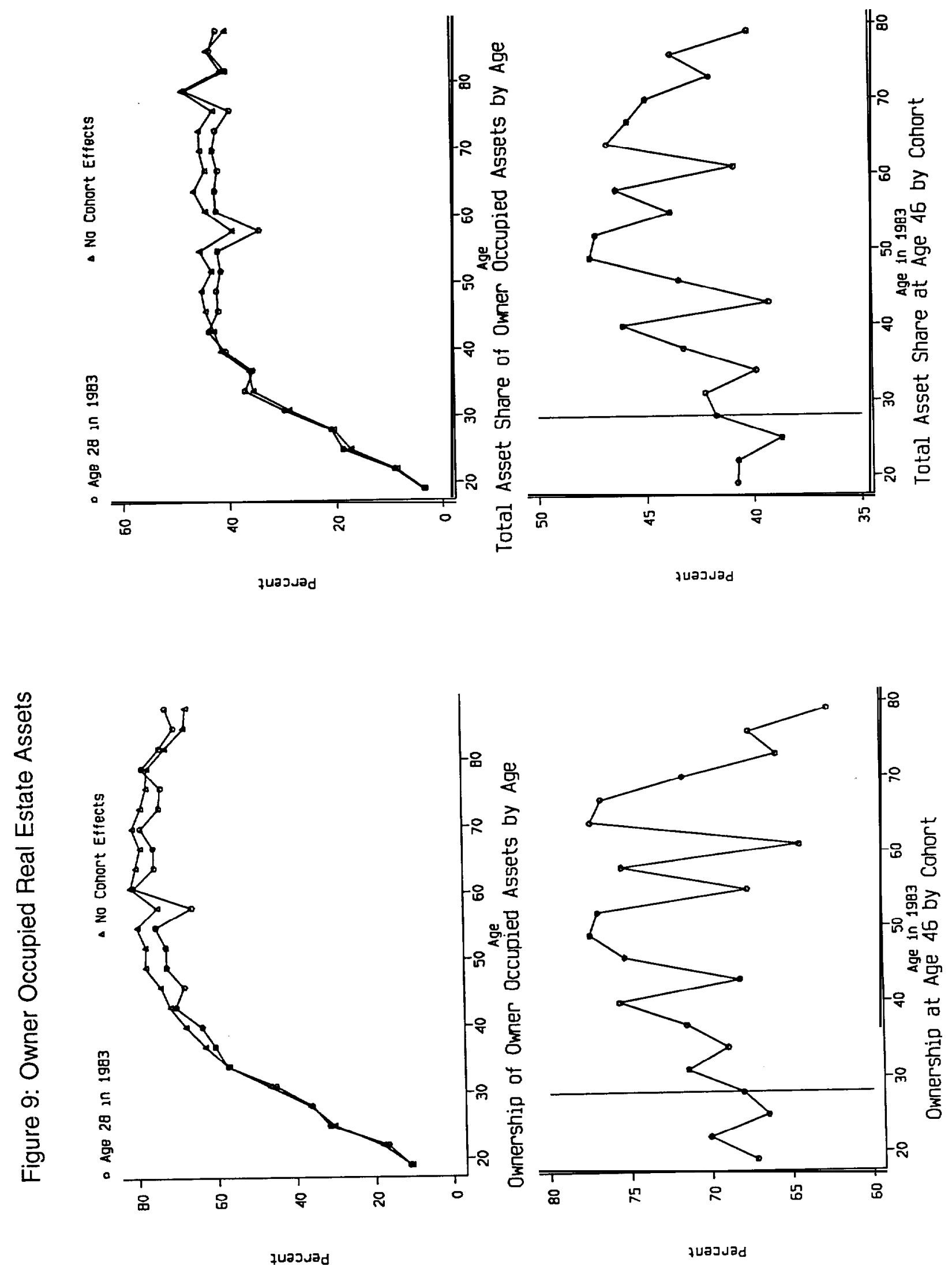

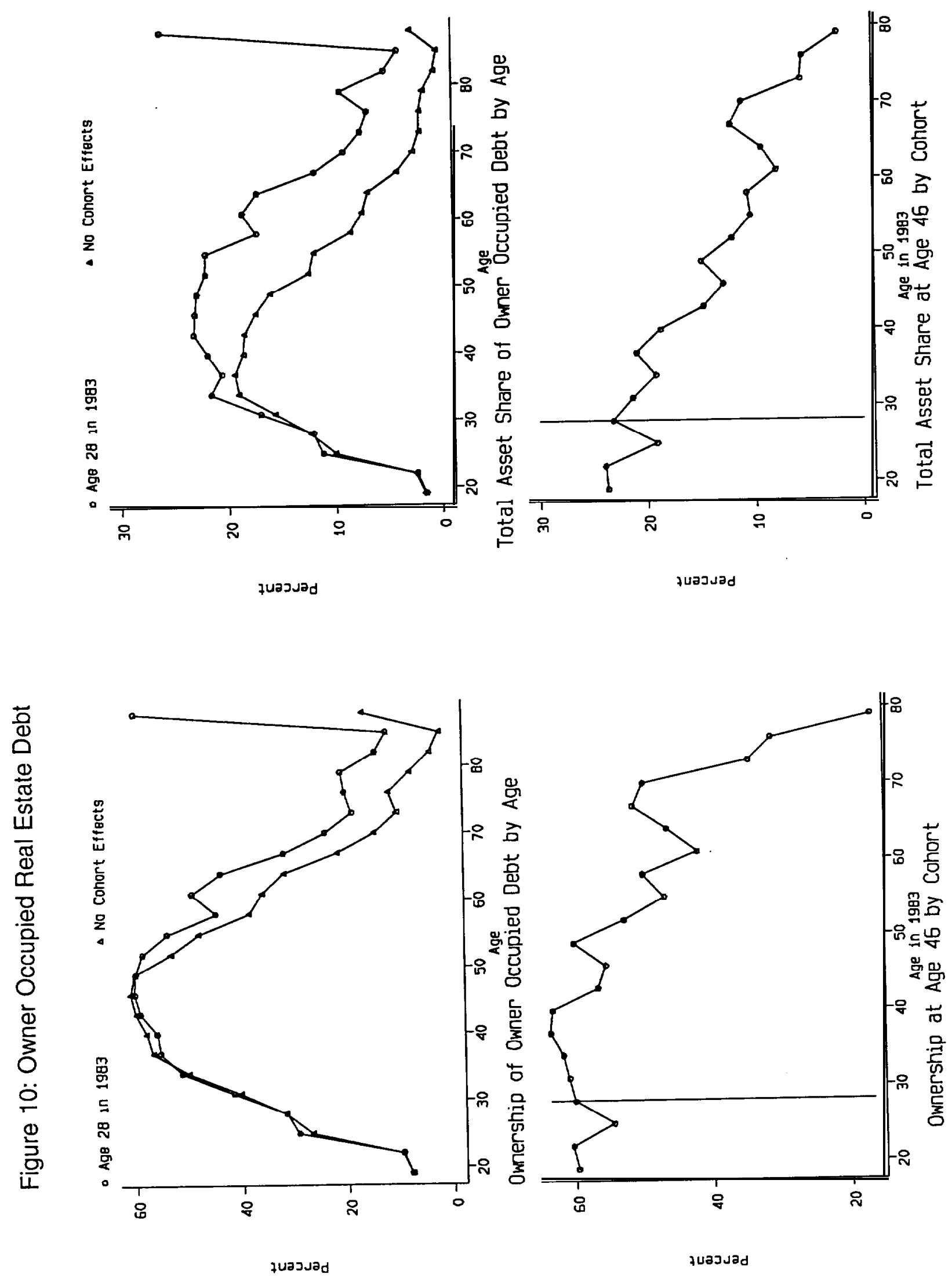

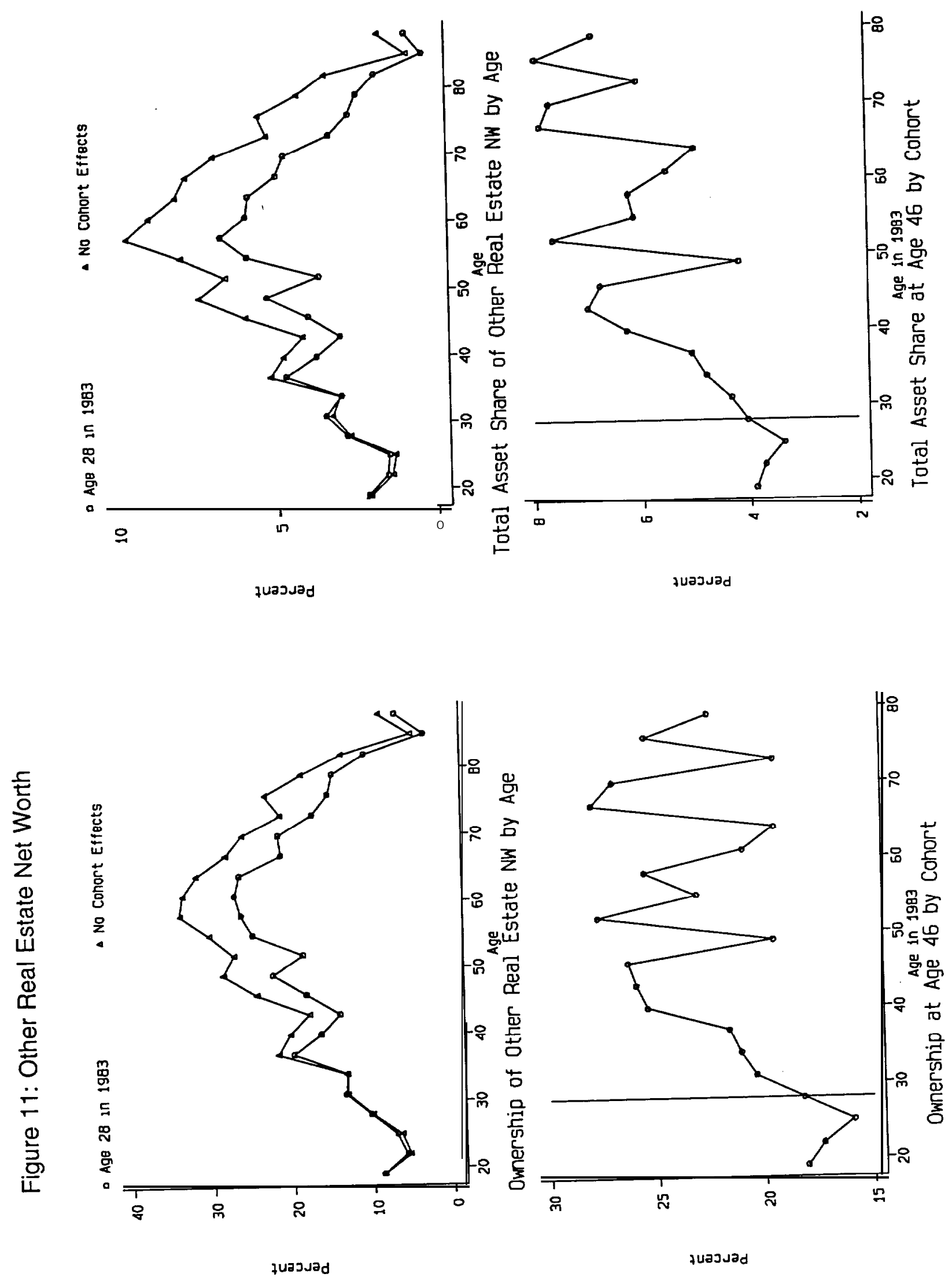

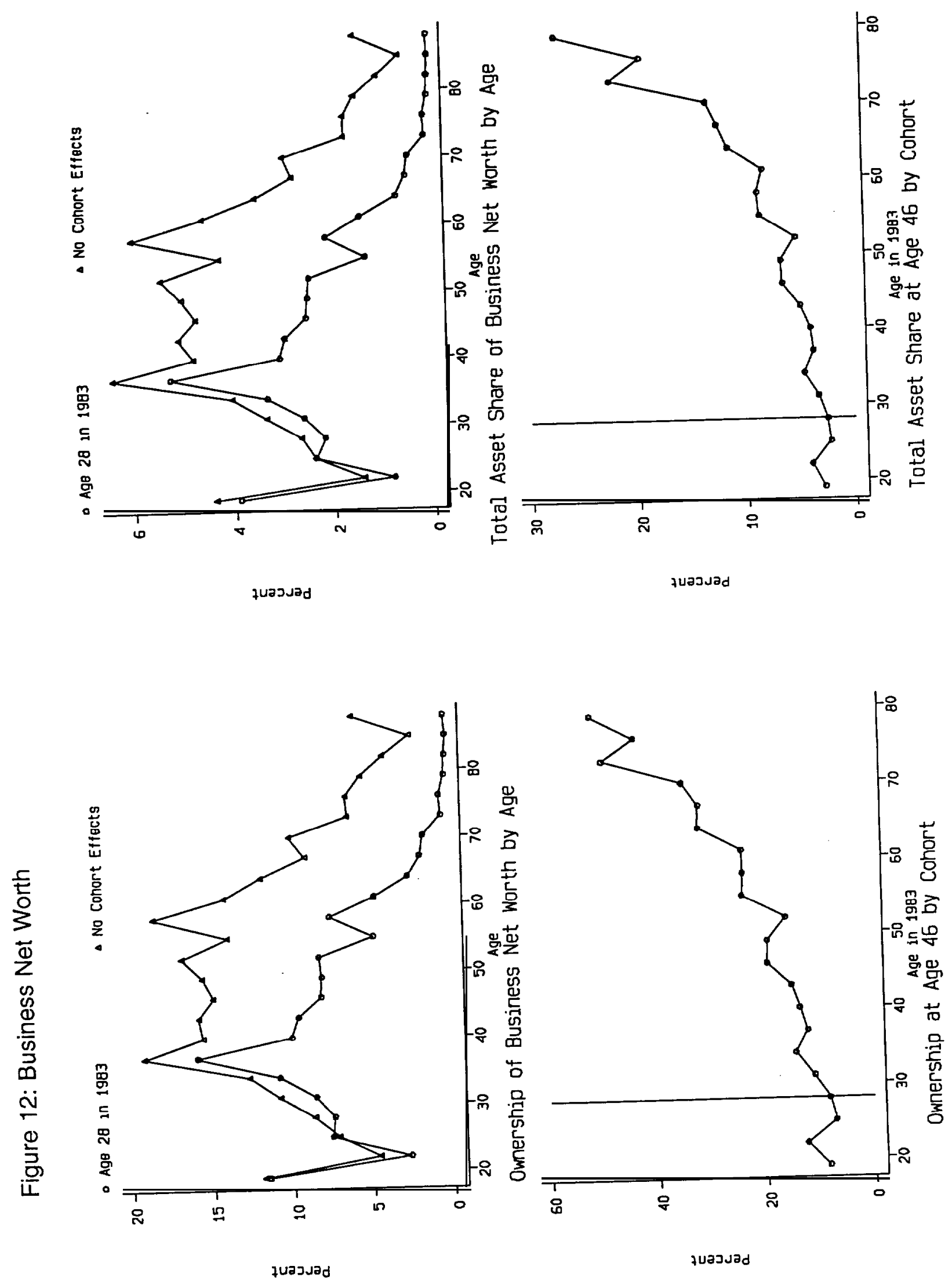